DOE/NV/11718-156

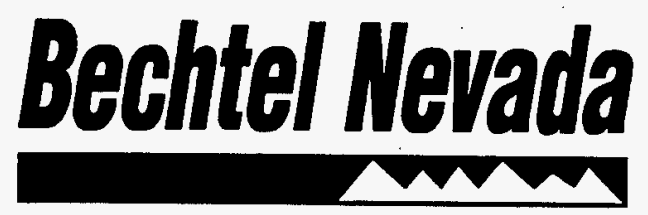

\title{
NATURE AND EXTENT OF LAVA-FLOW AQUIFERS BENEATH PAHUTE MESA, NEVADA TEST SITE
}

RECENED

NOV 101997

OSTI

September 1997

19980416108 


\section{DISCLAIMER}

This report was prepared as an account of work sponsored by the United States Government. Neither the United States nor the U.S. Department of Energy, nor any of their employees, makes any warranty, express or implied, or assumes any legal liability or responsibility for the accuracy, completeness, or usefulness of any information, apparatus, product, or process disclosed, or represents that its use would not infringe privately owned rights. Reference herein to any specific commercial product, process, or service by trade name, trademark, manufacturer, or otherwise, does not necessarily constitute or imply its endorsement, recommendation, or favoring by the United States Government or any agency thereof. The views and opinions of authors expressed herein do not necessarily state or reflect those of the United States Government or any agency thereof.

This report has been reproduced from the best available copy.

Available to DOE and DOE contractors from:

Office of Scientific and Technical Information

P.O. Box 62

Oak Ridge, TN 37831

For prices call (423) 575-8401

Available to the public from:

National Technical Infromation Service

U.S. Department of Commerce

5285 Port Royal Rd.

Springfield, VA 22161 


\title{
NATURE AND EXTENT OF LAVA-FLOW AQUIFERS BENEATH PAHUTE MESA, NEVADA TEST SITE
}

\section{by}

Lance B. Prothro and Sigmund L. Drellack, Jr.

\author{
Geology/Hydrology Group \\ Geotechnical Services \\ Bechtel Nevada
}

September 1997

\section{MASTER}

\section{BystrubUm}


Table of Contents

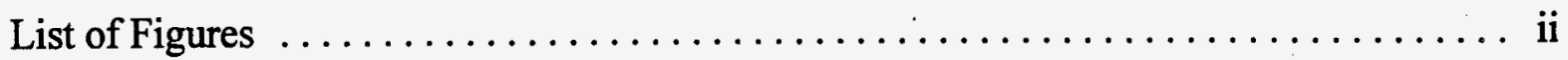

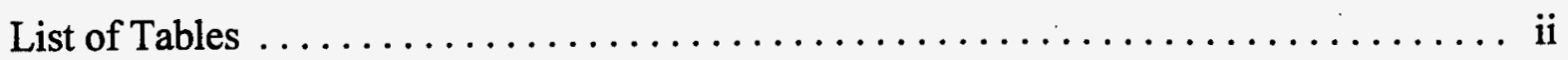

$1.0 \quad$ INTRODUCTION $\ldots \ldots \ldots \ldots \ldots \ldots \ldots \ldots \ldots \ldots \ldots \ldots \ldots \ldots \ldots \ldots \ldots$

2.0 HYDROGEOLOGIC SETTING $\ldots \ldots \ldots \ldots \ldots \ldots \ldots \ldots \ldots \ldots \ldots \ldots \ldots . \ldots \ldots$

2.1 Hydrogeologic Framework of Pahute Mesa $\ldots \ldots \ldots \ldots \ldots \ldots . \ldots \ldots$

2.2 Rhyolite Lava Flows . . . . . . . . . . . . . . . . . . 2-13

2.3 Rhyolite Lava Flows at Pahute Mesa .................. 2-15

3.0 PAHUTE MESA LAVA-FLOW AQUIFERS $\ldots \ldots \ldots \ldots \ldots \ldots \ldots \ldots \ldots \ldots$.

3.1 Hydraulic Characteristics of Pahute Mesa Lava-Flow Aquifers . . . . . . . 3-1

3.2 Distribution of Pahute Mesa Lava-Flow Aquifers . . . . . . . . . . . 3-3

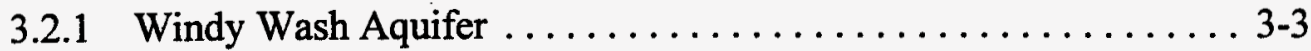

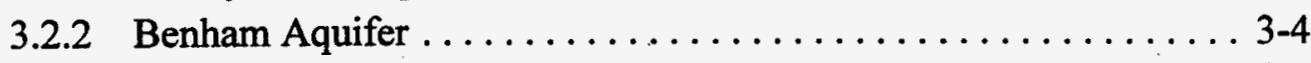

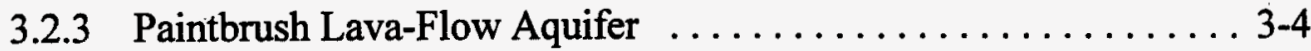

3.2.4 Calico Hills Zeolitized and Vitric Composite Units . . . . . . 3-11

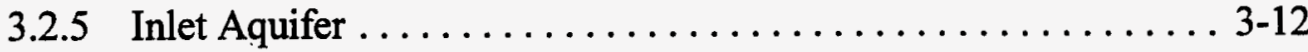

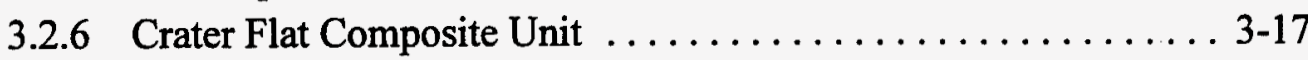

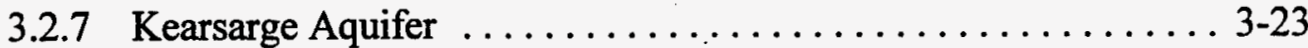

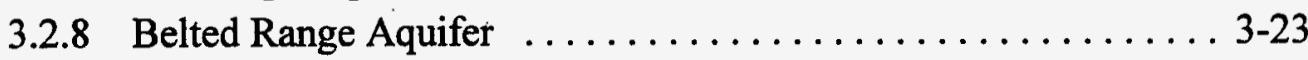

3.2.9 Pre-Belted Range Composite Unit . . . . . . . . . . . . 3-23

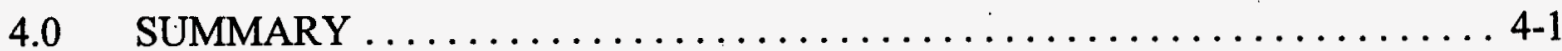

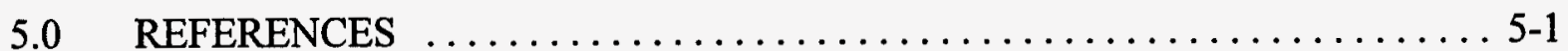


Location Map of the Pahute Mesa Study Area $\ldots \ldots \ldots \ldots \ldots \ldots .2-2$

Schematic Section Through a Typical Rhyolite Lava Flow ........ 2-14

Unit Extent Map of the Windy Wash Aquifer . . . . . . . . . . . 3-5

\section{List of Tables}

Number

\section{Title}

General Stratigraphic Section for the Pahute Mesa Study Area ....... 2-3

Volcanic Hydrogeologic Units at Pahute Mesa .............. 2-9

Hydrogeologic Framework for the Pahute Mesa Study Area ....... 2-10

Estimated Ranges of Hydraulic Conductivity

for the Primary Lava Flow Lithologies 


\subsection{INTRODUCTION}

Work is currently underway within the Underground Test Area subproject of the U.S. Department of Energy/Nevada Operations Office Environmental Restoration Program to develop corrective action plans in support of the overall corrective action strategy for the Nevada Test Site as established in the Federal Facility Agreement and Consent Order (FFACO, 1996). A closure plan is currently being developed for Pahute Mesa, which has been identified in the FFACO as consisting of the Western and Central Pahute Mesa Corrective Action Units. Part of this effort requires that hydrogeologic data be compiled for inclusion in a regional model that will be used to predict a contaminant boundary for these Corrective Action Units. Hydrogeologic maps have been prepared for use in the model to define the nature and extent of aquifers and confining units that might influence the flow of contaminated groundwater from underground nuclear tests conducted at Pahute Mesa.

Much of the groundwater flow beneath Pahute Mesa occurs within lava-flow aquifers (Blankennagel and Weir, 1973). An understanding of the distribution and hydraulic character of these important hydrogeologic units is necessary to accurately model groundwater flow beneath Pahute Mesa. This report summarizes the results of a study by Bechtel Nevada geologists to better define the hydrogeology of lava-flow aquifers at Pahute Mesa. The purpose of this study was twofold: (1) aid in the development of the hydrostratigraphic framework for Pahute Mesa, and (2) provide information on the distribution and hydraulic character of lava-flow aquifers beneath Pahute Mesa for more accurate computer modeling of the Western and Central Pahute Mesa Corrective Action Units (hereafter called the Pahute Mesa Study Area).

The study was conducted by assimilating and synthesizing geologic data from various sources (see Section 5), then using these data to prepare maps and cross sections to define the subsurface distribution of lava-flow aquifers beneath Pahute Mesa. Existing hydrologic data were also compiled, reviewed, and intergrated with geologic data to provide information on the hydrologic characteristics of Pahute Mesa lava-flow aquifers.

This summary report serves as a companion document to the more comprehensive hydrostratigraphic mapping and groundwater modeling efforts of the Pahutc Mics Study Area (Drellack and Prothro, in preparation), and is written for the use of technical and professional personnel involved in these efforts and other Underground Test Area activities. The report includes a brief description of the hydrogeologic setting of Pahute Mesa Because 
lava-flow aquifers at Pahute Mesa consist almost exclusively of rhyolite lava flows, a description of the geology and hydrology of rhyolite lava flows is also included. This discussion focuses on geologic characteristics specific to rhyolite lava flows at Pahute Mesa, but also includes background information on rhyolite lava flows in general. The report also describes the stratigraphic and geographic distribution of lava-flow aquifers at Pahute Mesa. Unit extent maps of hydrostratigraphic units containing lava-flow aquifers are included in the report. These maps are reduced from larger scale maps, and are intended to provide only general illustrations of the distribution of Pahute Mesa lava-flow aquifers. Digital, gridded versions of these maps will be provided to the modelers. Larger scale versions of the unit extent maps are available from the authors. 


\subsection{HYDROGEOLOGIC SETTING}

A brief synopsis of the geology and hydrogeology of eastern Pahute Mesa is presented in this section. More detail can be found in the references listed in Section 5 of this report. Also included are discussions of the geology of rhyolite lava flows in general, as well as characteristics specific to rhyolite lava flows at Pahute Mesa.

\subsection{Hydrogeologic Framework of Pahute Mesa}

Pahute Mesa is an elongated east-west volcanic plateau. Its eastern portion occupies the northwestern corner of the Nevada Test Site, including Areas 19 and 20 (Figure 2-1). The surface of Pahute Mesa consists mostly of ash-flow tuffs of the Thirsty Canyon and Timber Mountain Groups erupted from calderas located just west and south of the area, respectively (Byers and Cummings, 1967; Christiansen and Noble, 1968; Ekren et al., 1966; Frizzell and Shulters, 1990; Hinrichs et al., 1967; Lipman et al., 1966; Minor, et al., 1993; Noble et al., 1967). These rocks, along with volcanic rocks of the underlying Paintbrush Group, bury an older series of calderas that make up the Silent Canyon caldera complex. This caldera complex consists of at least two nested calderas, the Area 20 caldera and the older Grouse Canyon caldera (Sawyer and Sargent, 1989) (Figure 2-1). Both calderas were formed and subsequently filled by voluminous eruptions of tuff and lava of generally rhyolitic composition (Table 2-1). Total thickness of volcanic rocks beneath Pahute Mesa approaches five kilometers $(\mathrm{km})(16,400$ feet [f]]) (Ferguson et al., 1994).

The earliest conceptual geologic models for Pahute Mesa (Noble et al., 1968; Orkild et al. 1968; Orkild et al., 1969) recognized the presence of the Silent Canyon volcanic center, consisting of several thousand feet of Tertiary-age tuffs and lavas that erupted from one or more sources, now collapsed and buried. Later work defined the Area 20 and Grouse Canyon calderas within the Silent Canyon complex (Sawyer and Sargent, 1989). These early models depicted hypothetical caldera boundaries of arcuate shape, in keeping with classic "pistontype" collapse. However, other researchers have noted evidence suggesting that some caldera margins may have a more rectilinear shape (Kane et al., 1981 and Ferguson et al., 1994).

Ferguson et al. (1994), developed a comprehensive structural model for the Silent Canyon caldera complex based on an integration of drillhole, gravity, and seismic refraction data. The seismic refraction data showed that at two locations boundaries of both the Area 20 and Grouse Canyon calderas coincide exactly with linear Basin and Range faults mapped at the 


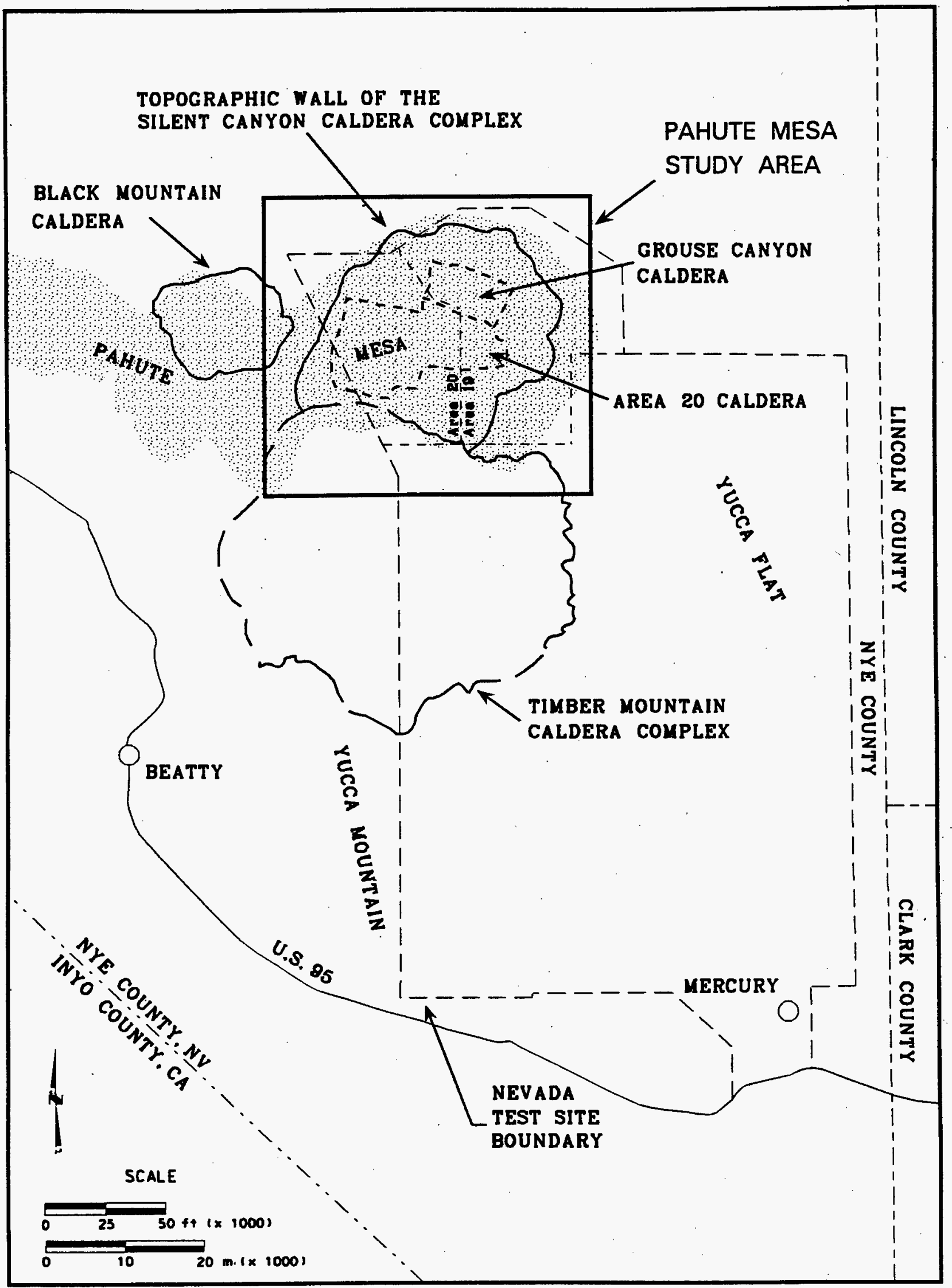

Figure 2-1

Location Map of the Pahute Mesa Study Area

(modified from Minor et al, 1993 and Ferguson et al., 1994) 
Table 2-1

General Stratigraphic Section for the Pahute Mesa Study Area.

(Modified from Los Alamos National Laboratory, 1992; and Ferguson et al., 1994.)

\begin{tabular}{|c|c|}
\hline Time-Rock Unit & Stratigraphic Assemblage \\
\hline $\begin{array}{l}\text { Grouse Canyon and Area } 20 \text { Caldera- } \\
\text { burying units }\end{array}$ & 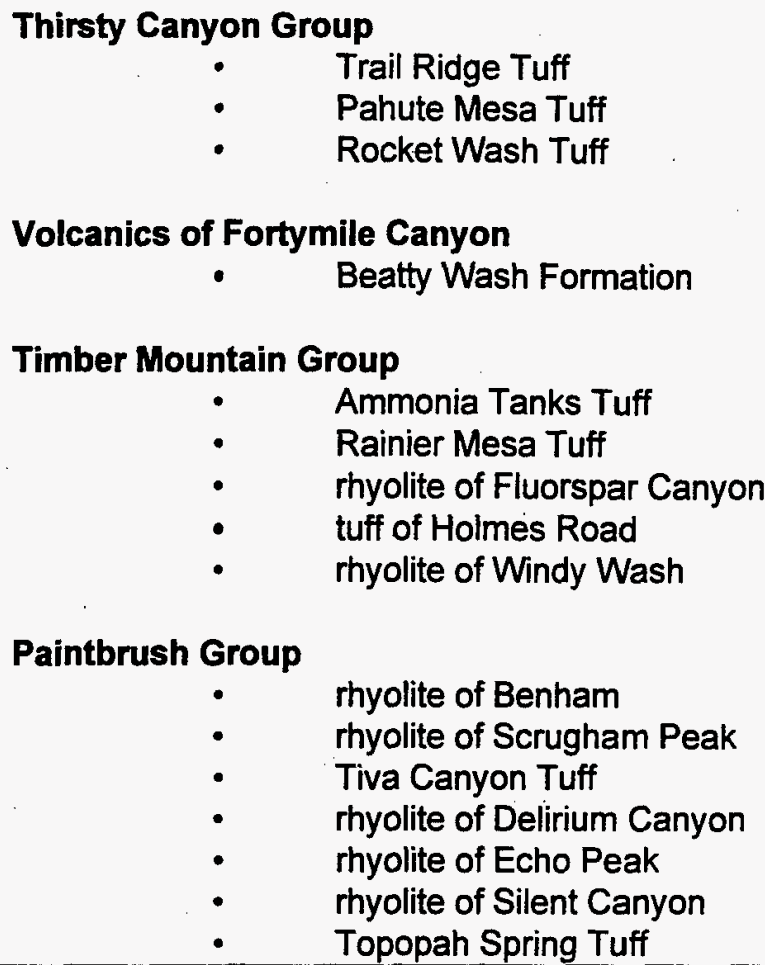 \\
\hline Area 20 Caldera-filling units & 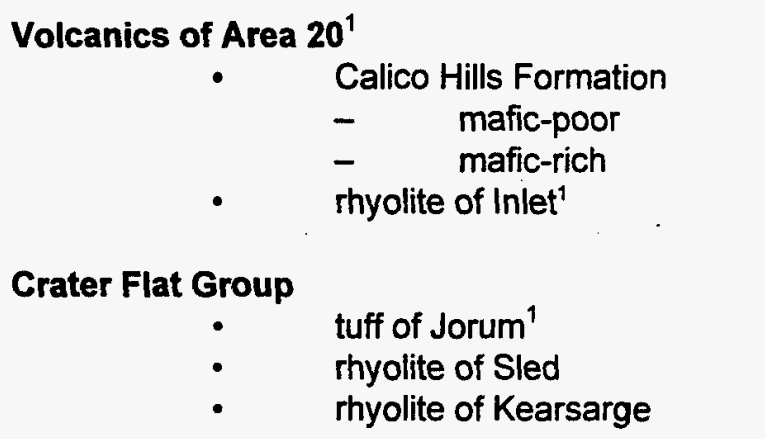 \\
\hline Area 20 Caldera-forming unit & Bullfrog Tuff \\
\hline Grouse Canyon Caldera-filling unit & $\begin{array}{c}\text { Belted Range Group } \\
-\quad \text { Dead Horse Flat Formation }\end{array}$ \\
\hline Grouse Canyon Caldera-forming unit & Grouse Canyon Tuff \\
\hline
\end{tabular}

1. Work in progress by Warren, et al. (in preparation) indicates that the Calico Hills Formation should be raised to group status, replacing the Volcanics of Area 20. Other units wrth in the Volcanics of Area 20, such as the rhyolite of Inlet, are better placed within the Crater Flat Group. Recent studies by Warren also indicate that the tuff of Jorum will be renamed the myolite of Jorum. 
surface, strong evidence for a coupling of caldera collapse within the Silent Canyon caldera complex with regional structure (i.e., Basin and Range faults). Thus, the Area 20 and Grouse Canyon calderas are likely to be asymmetric and rectilinear in shape, with boundaries that coincide with Basin and Range faults (Figures 2-2 and 2-3). Both calderas consist of an inner collapse zone resulting from initial caldera-forming eruptions, and a late-stage outer collapse zone formed during and after additional eruptions. The thickness and extent of many of the volcanic units beneath Pahute Mesa were heavily influenced by faulting during and after caldera formation (Ferguson et al., 1994).

The general hydrogeologic framework for Pahute Mesa and vicinity established by Blankennagel and Weir (1973) has provided the foundation for most subsequent hydrogeologic studies in the area. Laczniak et al. (1996) provide an excellent summary of the hydrogeologic setting of Pahute Mesa, and show that the major aquifers are volcanic units associated with both the Grouse Canyon and Area 20 calderas. They also show that the distribution of the aquifers is largely controlled by caldera boundaries. Consequently, a comprehensive structural model of the Silent Canyon caldera complex, such as that provided in Ferguson et al. (1994), is essential for developing a detailed comprehensive hydrogeologic model of Pahute Mesa, including the distribution of lava-flow aquifers. Therefore, this report and the Pahute Mesa hydrogeologic modeling effort will rely extensively on the data and interpretations presented in Ferguson et al. (1994).

The volcanic rocks that control groundwater flow beneath Pahute Mesa can be grouped into four volcanic hydrogeologic units based mainly on lithology and secondary alteration (Table 2-2). These units are lava-flow aquifers, welded-tuff aquifers, vitric-tuff aquifers, and tuff confining units. Groundwater beneath Pahute Mesa generally flows in a southwest direction, much of it through lava-flow aquifers (Blankennagel and Weir, 1973).

Water also flows through fractured welded ash-flow tuffs which form welded-tuff aquifers. Vitric bedded and nonwelded tuffs form vitric-tuff aquifers. Zeolitized bedded and nonwelded tuffs act as tuff confining units which inhibit the flow of groundwater (Blankennagel and Weir, 1973; and Laczniak et al., 1996). 

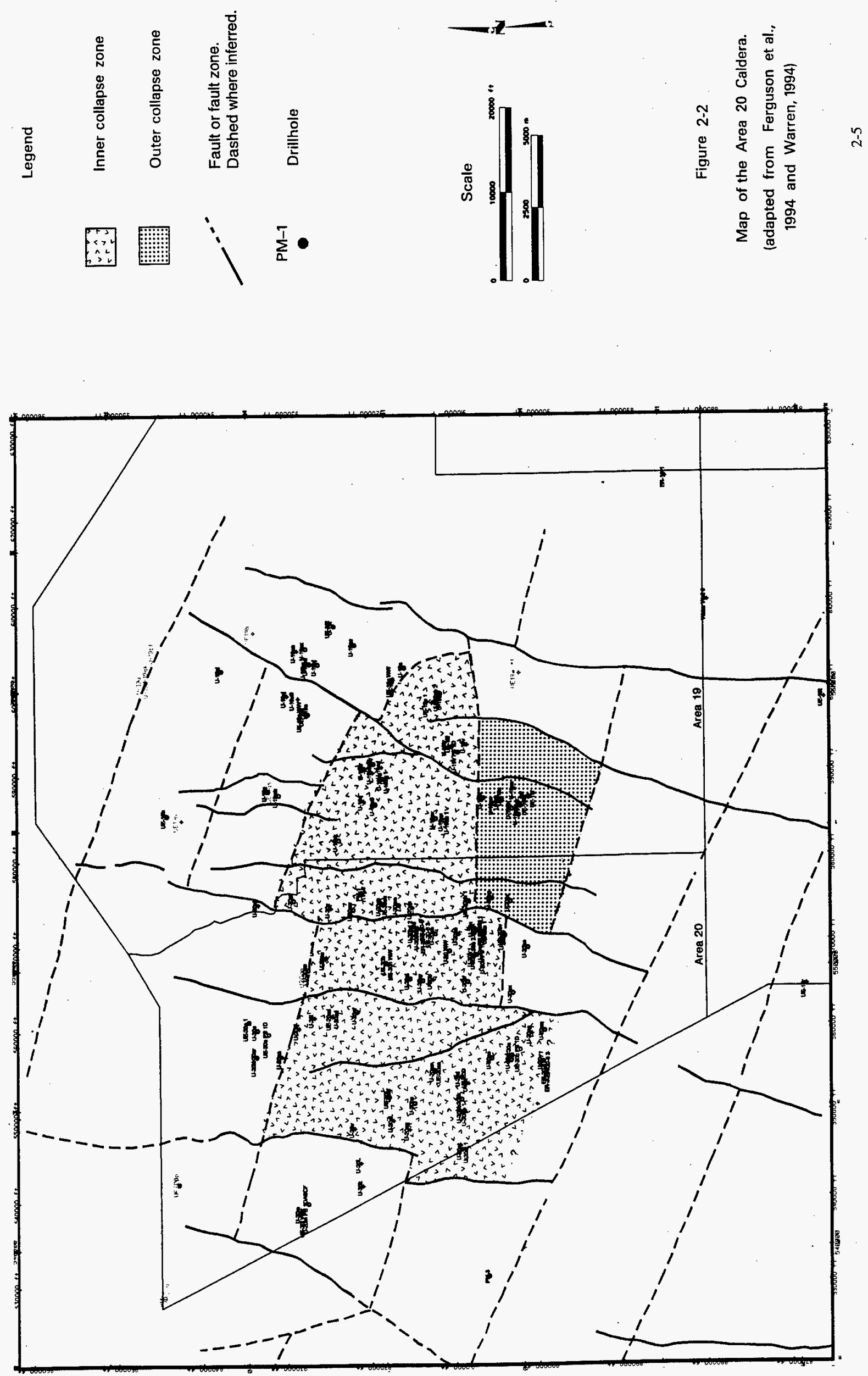

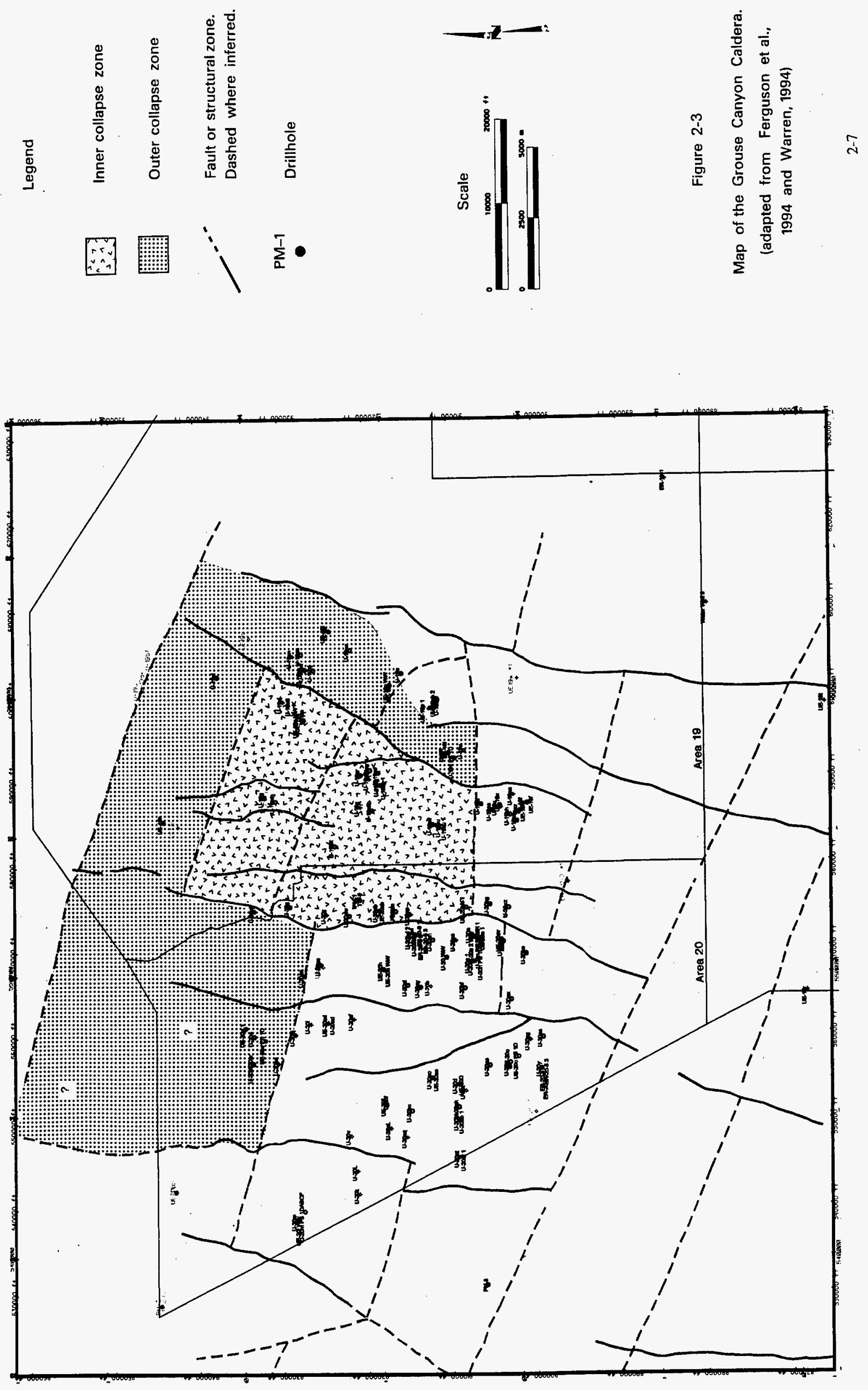
Table 2-2

Volcanic Hydrogeologic Units at Pahute Mesa

(Adapted from Blankennagle and Weir, 1973; Winograd and Thordarson, 1975; IT, 1996b; and Laczniak et al., 1996)

\begin{tabular}{|c|l|l||}
\hline $\begin{array}{c}\text { Hydrogeologic } \\
\text { Unit }\end{array}$ & \multicolumn{1}{c|}{$\begin{array}{c}\text { Typical } \\
\text { Lithologies }\end{array}$} & \multicolumn{1}{c|}{ Hydrologic Significance } \\
\hline $\begin{array}{c}\text { Vitric-Tuff Aquifer } \\
\text { (VTA) }\end{array}$ & $\begin{array}{l}\text { Bedded tuffs, ash-fall } \\
\text { and reworked tuffs; } \\
\text { vitric }\end{array}$ & $\begin{array}{l}\text { Constitutes a volumetrically minor hydrogeologic } \\
\text { unit. Generally not found below the static water } \\
\text { level due to tendency to become zeolitized (which } \\
\text { drastically reduces permeability) under saturated } \\
\text { conditions. Significant interstitial porosity (20 to 40 } \\
\text { percent). Generally insignificant fracture } \\
\text { permeability. }\end{array}$ \\
\hline $\begin{array}{c}\text { Welded-Tuff Aquifer } \\
\text { (WTA) }\end{array}$ & $\begin{array}{l}\text { Welded ash-flow tuff; } \\
\text { vitric to devitrified }\end{array}$ & $\begin{array}{l}\text { Either intra- or extra-caldera. Degree of welding } \\
\text { greatly affects interstitial porosity (less porosity as } \\
\text { degree of welding increases) and permeability } \\
\text { (greater fracture permeability as degree of welding } \\
\text { increases). }\end{array}$ \\
\hline $\begin{array}{c}\text { Tuff Confining Unit } \\
\text { (TCU) }\end{array}$ & $\begin{array}{l}\text { Zeolitized bedded tuff } \\
\text { with interbedded, but } \\
\text { less significant, } \\
\text { zeolitized, nonwelded } \\
\text { to partially welded ash- } \\
\text { flow tuffs }\end{array}$ & $\begin{array}{l}\text { May be saturated but measured transmissivities are } \\
\text { very low. Responsible for perched and/or semi- } \\
\text { perched water in overlying units. }\end{array}$ \\
\hline $\begin{array}{c}\text { Lava-Flow Aquifer } \\
\text { (LFA) }\end{array}$ & $\begin{array}{l}\text { Rhyolite lava flows, } \\
\text { includes flow breccias } \\
\text { (commonly at base) } \\
\text { and pumiceous zones } \\
\text { (commonly at top) }\end{array}$ & $\begin{array}{l}\text { Generally a caldera-filling unit. Hydrologically } \\
\text { complex; wide range of transmissivities; fracture } \\
\text { density and interstitial porosity differ with lithologic } \\
\text { variations. }\end{array}$ \\
\hline
\end{tabular}

As part of the groundwater modeling effort for the Pahute Mesa Study Area, the hydrogeologic units at Pahute Mesa were grouped into hydrostratigraphic units based on similar hydrogeologic character and stratigraphic position (Drellack and Prothro, in preparation). Table 2-3 depicts the hydrogeologic framework developed for the Pahute Mesa Study Area. It shows the 21 volcanic hydrostratigraphic units that are defined at Pahute Mesa and their relationships to stratigraphic and hydrogeologic units. The table also shows that 10 of the 21 hydrostratigraphic units contain lava-flow aquifer hydrogeologic units. These ten hydrostratigraphic units, which are highlighted in bold type in Table 2-3, will be discussed in more detail in Section 3.2. 
Table 2-3

Hydrogeologic Framework for the Pahute Mesa Study Area.

(Hydrostratigraphic units containing lava-flow aquifers are highlighted in bold type.)

(Page 1 of 3 )

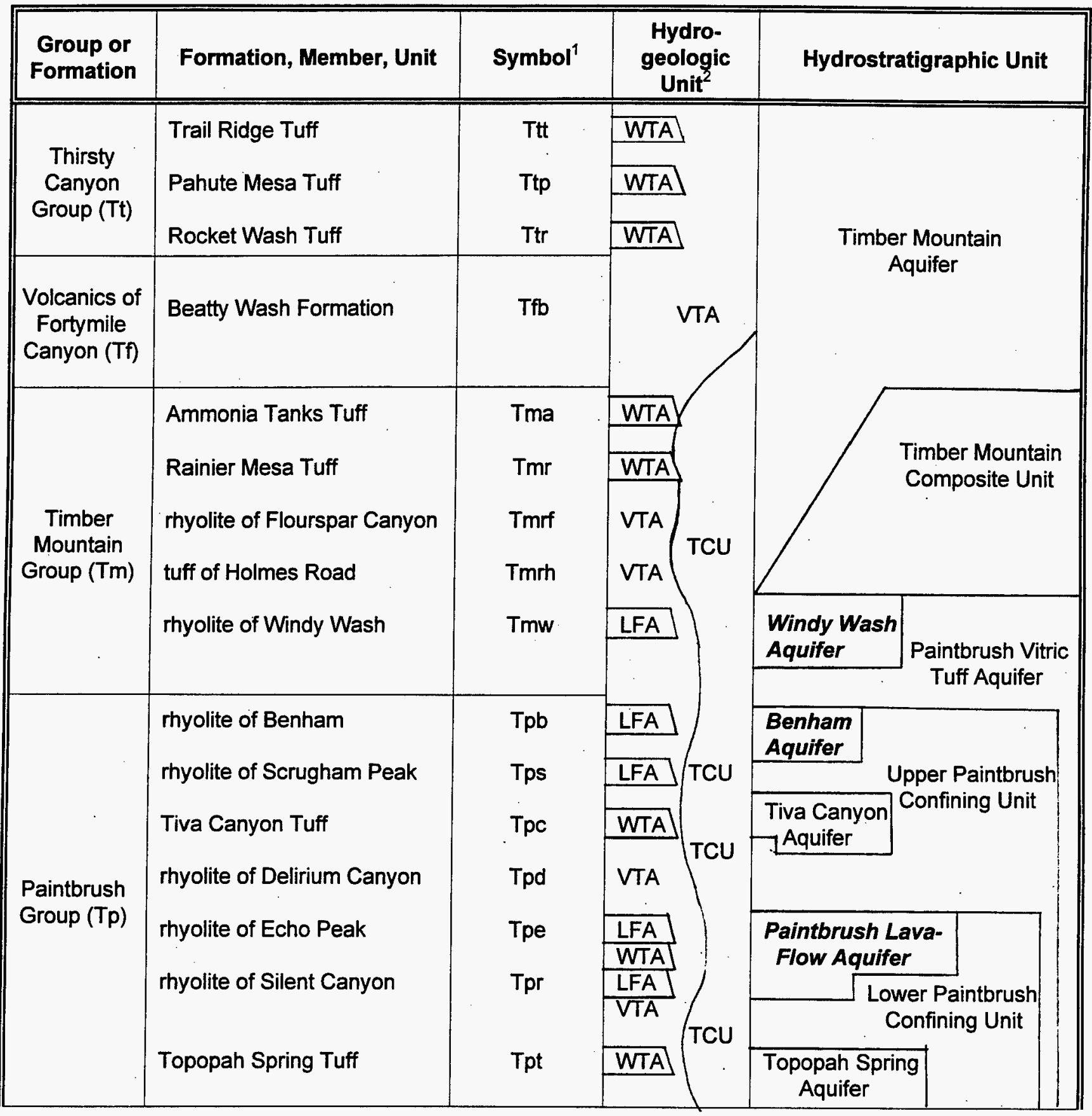


Table 2-3

Hydrogeologic Framework for the Pahute Mesa Study Area (Page 2 of 3)

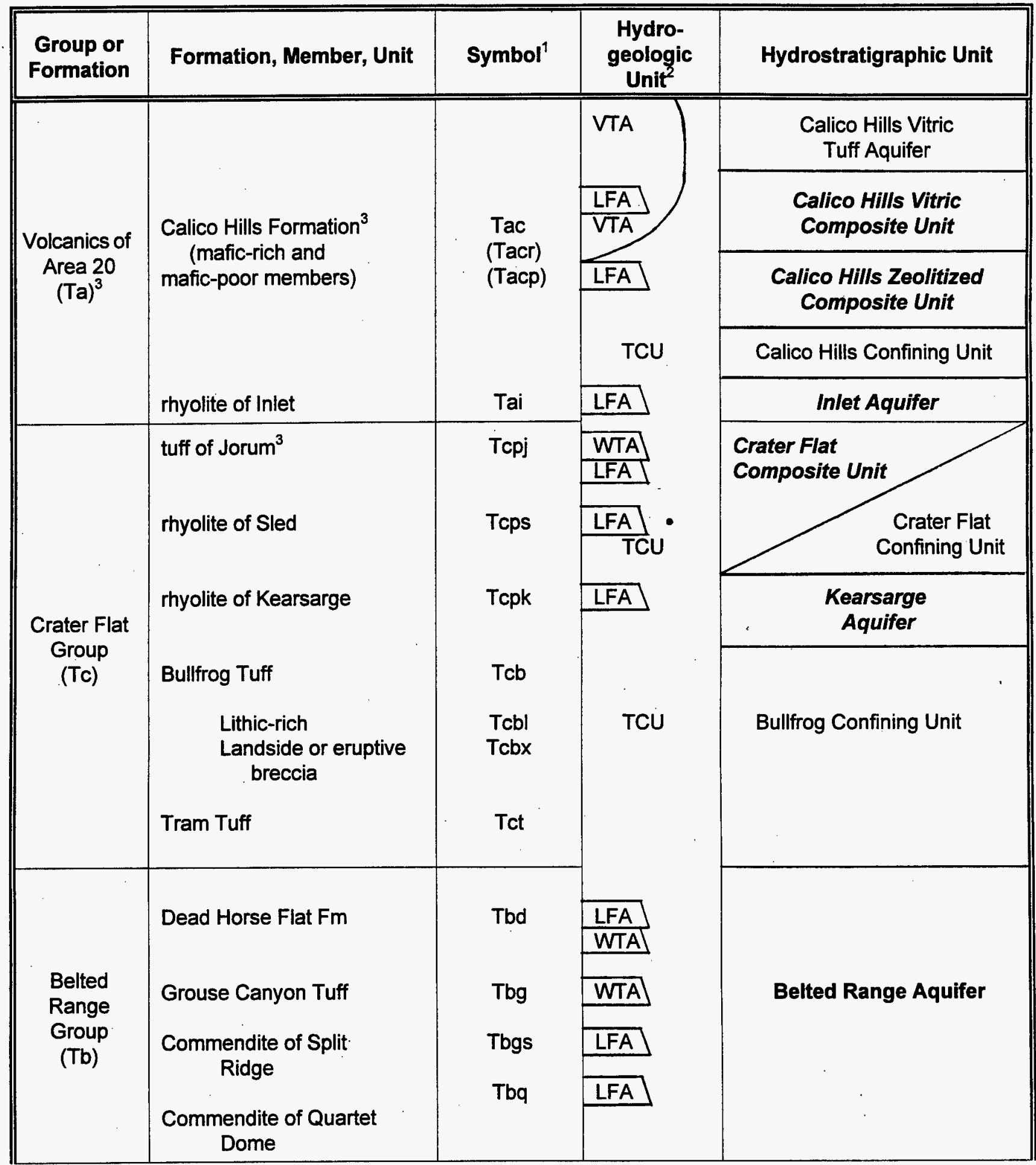


Table 2-3

Hydrogeologic Framework for the Pahute Mesa Study Area (Page 3 of 3 )

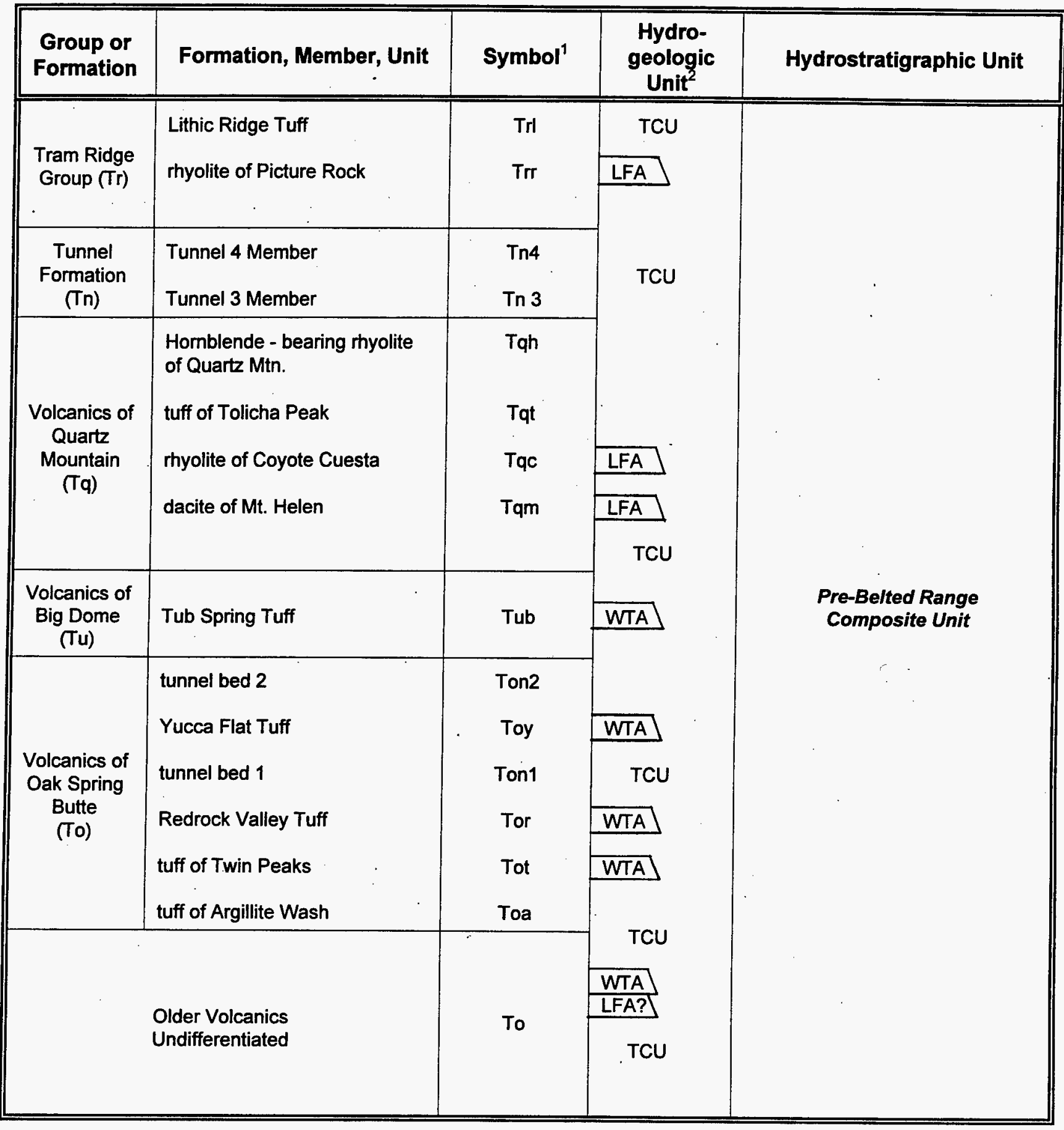

1. Stratigraphic nomenclature from Ferguson et al., 1994.

2. See Table 2-2 for definitions of acronyms.

3. Work in progress by Warren, et al. (in preparation) indicates that the Calico Hills Formation should be raised to group status, replacing the Volcanics of Area 20. Other units within the Volcanics of Area 20, such as the rhyolite of Inlet, are better placed within the Crater Flat Group. Recent studies by Warren also indicate that the tuff of Jorum will be renamed the rhyolite of Jorum. 


\subsection{Rhyolite Lava Flows}

Because lava-flow aquifers at Pahute Mesa consist almost entirely of rhyolite lava flow lithologies, it is useful to examine the geology of rhyolite lava flows to determine the hydrogeologic characteristics of lava-flow aquifers.

Rhyolite lava flows are usually associated with calderas and other volcanic depressions. In many places, the extrusion of rhyolite lava results from the resurgence of magma beneath calderas after caldera-forming eruptions of tuff, and subsequent collapse. Faults associated with caldera formation are the main conduits for resurging magma to reach the surface to form rhyolite lava flows. The viscous nature of rhyolite lava results in the formation of bulbous domes, mesas, and elongated plateaus called coulees. All these features are relatively thick in relation to their areal extent and have steep, abrupt flanks. In some instances, significant amounts of tuff may be ejected, forming a cone prior to the extrusion of lava. This tuff cone may then be filled and partially or completely buried by lava. Pyroclastic eruptions of tuff may continue during and after extrusion of lava (Cas and Wright, 1987).

Individual rhyolite lava flows can consist of a variety of lithologies. A typical flow consists of a stony rhyolite center surrounded by a carapace of obsidian, which is itself surrounded by pumiceous lava and flow breccia (Figure 2-4). The stony lava interior is usually hard, dense, and devitrified. The obsidian is usually dark and vitreous and may occur as layers and lenses within other lithologies. More pumiceous lava may occur near the margins of the flow, particularly near the top. Flow breccia, which often is present at the top, base, and distal edges of a lava flow, consists of clasts of obsidian, pumiceous lava, and stony lava within a softer, typically pumiceous matrix. Pyroclastic eruptions during extrusion of lava may result in small amounts of tuff being incorporated into the flow (Cas and Wright, 1987).

A variety of fractures can form within rhyolite lava flows in response to cooling and flow. Shrinkage or cooling fractures similar to columnar jointing in basalt flows may form in the stony lava interior. Extension fractures related to stretching and flow folding may be present, particularly near the surface of the flow. Platy jointing or subhorizontal sheetung joints may form in the central portions of the flow (Maley, 1994). Additional fractures may form due to post-depositional tectonic processes such as faulting and folding. 


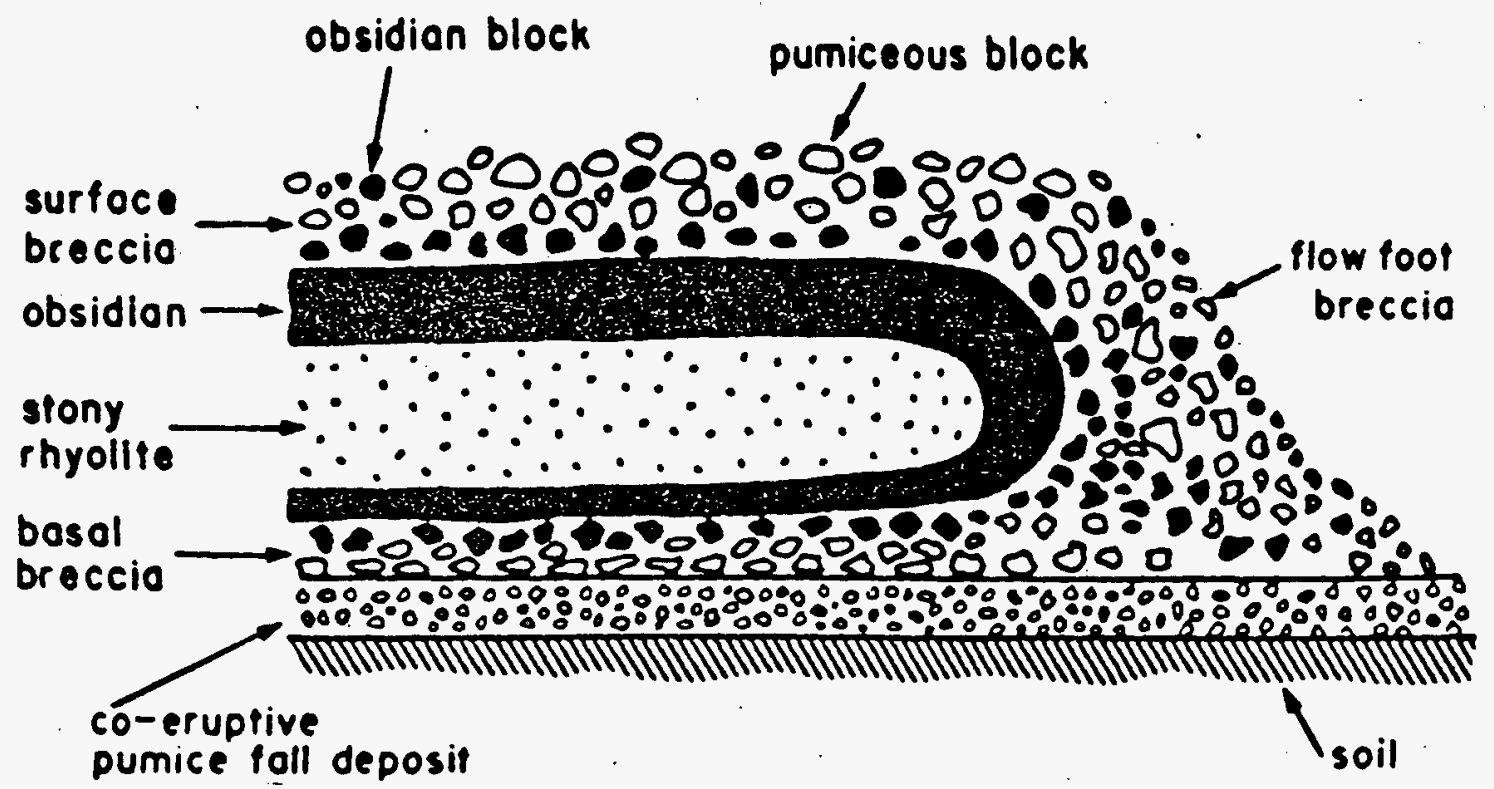

Figure 2-4

Schematic Section Through a Typical Rhyolite Lava Flow (from Cas and Wright, 1987) 


\subsection{Rhyolite Lava Flows at Pahute Mesa}

At Pahute Mesa, thick and extensive caldera-filling lava flows of rhyolitic composition occur within both the inner and outer collapse zones of the Area 20 and Grouse Canyon calderas. Less extensive rhyolite lava flows associated with caldera-burying units are also present at Pahute Mesa (Table 2-1). The sources of the rhyolite lavas appear to be caldera-related structures, particularly the intersections of these structures (Ferguson et al., 1994; Warren et al., 1989). Subsurface mapping indicates that some rhyolite lava flows at Pahute Mesa formed mesas and coulees. Thick piles of tuff associated with some lava flows indicate that tuff cones are also present beneath Pahute Mesa (Warren et al., 1989).

Individual rhyolite lava flows at Pahute Mesa consist mostly of devitrified stony lava. Pumiceous lava and flow breccia are also common, particularly near the top, base, and distal edges of individual flows. Obsidian is rarely present, usually as a basal vitrophyre (Warren, 1994).

An attempt was made during this study to define in more detail the distribution of the various lithologies within individual rhyolite lava flows at Pahute Mesa. Geophysical logs and lithologic data were analyzed in an attempt to correlate lava flow lithologies between drillholes in preparation for mapping the distribution of the various lithologies. The source of most of these data (Warren, et al., in preparation) is an extensive compilation of lithologic, stratigraphic, petrographic, and geochemical data from drillholes and surface grab samples from the Nevada Test Site and vicinity. Contributions to this database have been made by the U.S. Geological Survey, the national laboratories, and Department of Energy contractors.

It was anticipated that maps illustrating the distribution of lava flow lithologies within individual lava flows might allow for more accurate modeling of groundwater flow. However, this exercise proved mostly unsuccessful for the following reasons:

- Rhyolite lava flows at Pahute Mesa tend to coalesce and overlap, forming a complex three-dimensional network of lava flow lithologies.

- Separate lava flows that occur within a particular geographic area and stratigraphic interval are usually petrologically and mineralogically similar. This makes it extremely difficult to distinguish individual lava flows with confidence, and almost impossible to discern the various incorporated lithologic units. 
- Because of the difficulty in identifying the various rhyolite lava lithologies, many lava flow lithologies were reported simply as "lava" (Warren, 1997, personal communication). For example, flow breccia was often unrecognized because only fragments from the stony lava component are usually preserved in drill cuttings samples.

In light of these difficulties, a simple statistical analysis was performed on thicknesses of the various lava flow lithologies in Pahute Mesa drillholes as listed in Warren et al., (in preparation). This was done to gain a better understanding of the relative amounts of the various lithologies that occur within intervals of lava at Pahute Mesa. For each stratigraphic unit, the thickness of each lava flow lithology reported from a drillhole was divided by the total thickness of lava penetrated. The resulting percentages were then averaged for each stratigraphic unit. These averaged percentages of lava flow lithologies were very similar for the various stratigraphic units, averaging about 80 percent stony lava and vitrophyre, with the remainder being split about equally between pumiceous lava and flow breccia.

Unfortunately, because "lava" was the "default" description for rhyolite lava flow lithologies in the past, stony lava is probably over-represented in our analysis, which means that the actual percentage is somewhat less than 80 percent. It should be noted that this is just a gross average, and the actual lithologic makeup of a lava flow at any given locality may be considerably different. For example, a lava flow may be almost 100 percent flow breccia along its margins; whereas, in the center of the flow, it may consist of almost 100 percent stony lava.

In spite of these problems, it may be possible to characterize in some detail the distribution of rhyolite lava flow lithologies from particular stratigraphic intervals in certain local areas at Pahute Mesa that have a sufficient density of drillholes. However, at a minimum, this would require a thorough reexamination of the available data such as drill cuttings, core, and geophysical logs.

A study consisting of detailed fracture analyses of volcanic cores from Pahute Mesa was recently conducted by geologists of Bechtel Nevada, International Technology Corporation, Daniel B. Stephens and Associates, and Geotrans, Inc. (IT, 1996a). The study included numerous cores from rhyolite lava flows, and it was found that in these holes, Pahute Mesa lava flows average 0.67 fractures per vertical foot of core. However, open fractures have a density of only 0.12 fractures per vertical foot. Apertures average less than 1 millimeter (0.04 inch) in width. Open fractures are rarely completely open, being partially filled mainly 
by zeolites and chalcedony. The majority of fractures dip greater than 60 degrees, suggesting subhorizontal sheeting may not be well developed in lava flows at Pahute Mesa. Numerous randomly oriented irregular fractures were observed associated with flow breccia. Most of these fractures are closed, but solution openings were observed along some of the fractures. Slickensides observed on fracture mineral coatings indicate that postdepositional tectonic processes have affected the lava flows. However, it is unclear to what extent these processes created fractures or reactivated preexisting fractures.

The above observations are generally consistent with those made by Blankennagel and Weir (1973). They observed that the number of fractures per foot of core from rhyolite lava flows at Pahute Mesa ranged from 0 to 4.3. Most of the fractures dipped greater than 60 degrees and were tight to slightly open. Manganese oxide coated most of the fractures, and at depth some were filled with quartz. 
This Page Intentionally Left Blank 


\subsection{PAHUTE MESA LAVA-FLOW AQUIFERS}

This section describes the hydraulic characteristics and distribution of lava-flow aquifers beneath Pahute Mesa. Because few hydrologic test data exist for discrete lava flow lithologies, the hydraulic properties of these lithologies are derived in part from properties of better known and more familiar volcanic hydrogeologic units that can be assumed to be hydraulically similar to lava flow lithologies.

\subsection{Hydraulic Characteristics of Pahute Mesa Lava-Flow Aquifers}

As discussed in Section 2, individual rhyolite lava flows at Pahute Mesa can display considerable lithologic variation. Because the various lithologies tend to have different hydraulic properties, lava-flow aquifers can vary considerably in hydrologic character.

Stony lava is usually hard, dense, and devitrified, with low matrix porosity and permeability. However, this lithology usually contains the most fractures and therefore is believed to be a main conduit for groundwater flow within lava-flow aquifers. Likewise, the vitrophyric zones are also brittle and susceptible to fracturing, and thus are also believed to readily transmit groundwater. Because stony lava and welded tuff have similar physical properties and tendency to develop cooling fractures, stony lava can be assumed to have hydraulic properties similar to those of a welded-tuff aquifer (Table 3-1).

Table 3-1

Estimated Ranges of Hydraulic Conductivity for the Primary Lava Flow Lithologies

\begin{tabular}{||c|c|c|c|}
\hline \multicolumn{2}{|c|}{ Lava Flow Lithology } & Comparable Hydrogeologic Unit & $\begin{array}{c}\text { Hydraulic } \\
\text { Conductivity } \\
\text { (Meters/Day) }\end{array}$ \\
\hline \hline \multirow{2}{*}{ Pumiceous Lava } & Vitric & Vitric-Tuff Aquifer & $0.1-1$ \\
\cline { 2 - 5 } & Zeolitic & Tuff Confining Unit & $0.001-0.7$ \\
\hline Stony Lava and Vitrophyre & $\begin{array}{l}\text { Welded-Tuff Aquifer } \\
\text { Flow Breccia }\end{array}$ & $\begin{array}{l}\text { Tuff Confining Unit } \\
\text { Welded-Tuff Aquifer }\end{array}$ & $0.1-20$ \\
\hline \multicolumn{2}{|c|}{ Flid - } \\
\hline
\end{tabular}

1. Due to the paucity of hydrologic data for discrete lava flow lithologies, the given hydraulic property ranges may include measurements for the comparable hydrogeologic unit shown in Column 2 . The values presented are the authors' qualitative estimates based on data from published (IT, [1995] and Blankennagle and Weir [1973]) and unpublished sources. 
In contrast to stony lava and vitrophyre, pumiceous lava is relatively soft and in many places has few fractures. Vitric pumiceous lava (i.e., unaltered) is similar in many aspects to vitric nonwelded and bedded tuff. Thus, intervals of vitric pumiceous lava probably have hydraulic properties similar to those of a vitric tuff aquifer (Table 3-1). Below the water table, pumiceous lava is generally zeolitized and therefore is probably similar hydraulically to a tuff confining unit (Table 3-1). However, unlike bedded and nonwelded tuff, pumiceous lava commonly remains vitric for some depth below the water table (Warren, 1994).

The softer portions of flow breccia, such as the matrix and pumiceous clasts, also are usually zeolitized where saturated. Because the relative proportions of the various constituents can differ within a flow breccia, the hydrogeologic properties can also be different, resulting in a flow breccia that readily transmits groundwater at one place in the aquifer and not at another. Therefore, hydraulic properties of flow breccia probably range between those of tuff confining unit and welded-tuff aquifer (Table 3-1). Basal flow breccias are typically very permeable and therefore probably have hydraulic properties similar to those of stony lava and welded-tuff aquifer (Warren, 1994).

Many lava-flow aquifers are composed of several coalescing and overlapping individual lava flows, each with its own distribution of lava flow lithologies. This results in a very complex and unpredictable three-dimensional network of lava flow lithologies within lava-flow aquifers. In addition, the eruption of tuff prior to, during, and after the extrusion of lava may result in the incorporation of variable thicknesses of tuff within and around lava flows. This heterogeneity results in tortuous groundwater flow paths within lava-flow aquifers. Consequently, on a gross scale lava-flow aquifers probably transmit groundwater less effectively than welded-tuff aquifers. However, in certain places within the aquifer (such as the basal flow breccia and base and distal edges of the stony and vitrophyric portions), the aquifer can have permeability equal to or possibly greater than that of welded-tuff aquifer. Zones of higher permeability within lava-flow aquifers also occur in the vicinity of faults (Blankennagel and Weir, 1973).

Drillhole data indicate that on an even larger scale, periods of rhyolite lava deposiuon are often preceded or followed by periods of extensive pyroclastic eruptions resulung in the deposition of thick deposits of tuff. Thus, thick intervals of lava-flow aquifers ma! be separated by thick intervals of tuff confining units, resulting in the compartmentalszation of lava-flow aquifers. This is observed in the Calico Hills Zeolitized Composite I nn? 
hydrostratigraphic unit, where at least three thick lava-flow aquifers are separated by intervals of tuff confining units.

\subsection{Distribution of Pahute Mesa Lava-Flow Aquifers}

Because one of the major objectives of this study was to aid in the development of the hydrostratigraphic framework for the Pahute Mesa Study Area modeling process, this section describes the distribution of lava-flow aquifers relative to that framework. Each hydrostratigraphic unit containing lava-flow aquifers is briefly described and the distribution of lava-flow aquifers within the unit is discussed. A unit extent map is provided for each of the ten hydrostratigraphic units containing lava-flow aquifers. The unit extent maps consist of structure contour maps of the top of each of the hydrostratigraphic units, and are intended to show the general distribution of the units. It should be noted that each map depicts all Pahute Mesa drillholes, and not just drillholes that encounter a particular unit. The maps were produced using stratigraphic and lithologic data from Pahute Mesa drillholes as reported in Warren et al. (in preparation). Conceptual information on the structural evolution of the Silent Canyon caldera complex and the depositional patterns of associated volcanic rocks presented in Ferguson et al. (1994) and Warren et al. (1989) was also utilized.

Some of the ten hydrostratigraphic units discussed below consist entirely of a single interval of lava-flow aquifer, while others contain several intervals of lava-flow aquifers, along with intervals of welded and vitric tuff aquifers and tuff confining units. The term "composite unit" is used in this report and in the Pahute Mesa Study Area modeling effort to designate hydrostratigraphic units that consist of a variety of volcanic hydrogeologic units; more specifically, interbedded aquifers (primarily lava-flow aquifers) and confining units.

Although lava-flow aquifers within caldera-burying rocks (e.g., Timber Mountain and Paintbrush Groups) are located mostly above the water table and unsaturated, they are included in the discussion below because: (1) much more data exists for these shallower units, thus allowing for a better characterization of lava-flow aquifers in general which can be applied to the deeper and hydrologically more important units; (2) some nuclear tests were conducted within these units; and (3) perched water may be present within some of these units.

\subsubsection{Windy Wash Aquifer}

The Windy Wash Aquifer is composed of a single lava-flow aquifer consisting of lava of the rhyolite of Windy Wash, a caldera-burying unit of the Timber Mountain Group. The 
occurrence of the unit is generally centered around U-20a \#2WW in east-central Area 20 (Figure 3-1). The Windy Wash Aquifer has a maximum thickness of approximately 180 meters $(\mathrm{m})(591 \mathrm{ft})$ and is very limited in extent. The lava appears to have originally formed a small mesa with a relatively flat top and base and steep, abrupt flanks typical of rhyolite lava flows. The eastern margin of the flow appears to have piled up against a . topographic barrier formed by the West Greeley fault.

The Windy Wash Aquifer is unsaturated.

\subsubsection{Benham Aquifer}

Like the Windy Wash Aquifer, the Benham Aquifer consists of a single lava-flow aquifer. It consists of rhyolite lava flow lithologies of the rhyolite of Benham that occur mostly west of the intersection of the Boxcar and West Boxcar faults in southwestern Area 20 (Figure 3-2). The Benham Aquifer is limited in extent and generally centered around U-20c where $347 \mathrm{~m}$ $(1,138 \mathrm{ft})$ of the aquifer were penetrated. Along the southern margin of the hydrostratigraphic unit in the vicinity of U-20as, it is underlain by thick zeolitized bedded tuff also of the rhyolite of Benham, suggesting the formation of a tuff cone prior to extrusion of lava. The origin of the tuff cone and related lava is probably the intersection of the Boxcar and West Boxcar faults (Warren et al., 1989).

Only the lower portions of the northern and northeastern margins of the aquifer are below the water table. However, anomalously high water levels occur within the aquifer at U-20bb and U-20ao (O'Hagan and Laczniak, 1996). This probably represents perched water.

\subsubsection{Paintbrush Lava-Flow Aquifer}

The Paintbrush Lava-Flow Aquifer consists of two lava-flow aquifers and a welded-tuff aquifer. These aquifers are composed of lithologies assigned to both the rhyolite of Silent Canyon and the rhyolite of Echo Peak, caldera-burying units of the Paintbrush Group. The Paintbrush Lava-Flow Aquifer is confined mainly to western Area 19 between the Scrugham Peak and West Greeley faults (Figure 3-3). The maximum measured thickness of the unit is at Well ER-20-2\#1 where $440 \mathrm{~m}(1,444 \mathrm{ft})$ was penetrated, including $313 \mathrm{~m}(1,027 \mathrm{ft})$ of lava and $127 \mathrm{~m}(417 \mathrm{ft}$ ) of welded tuff (Warren et al., in preparation). 


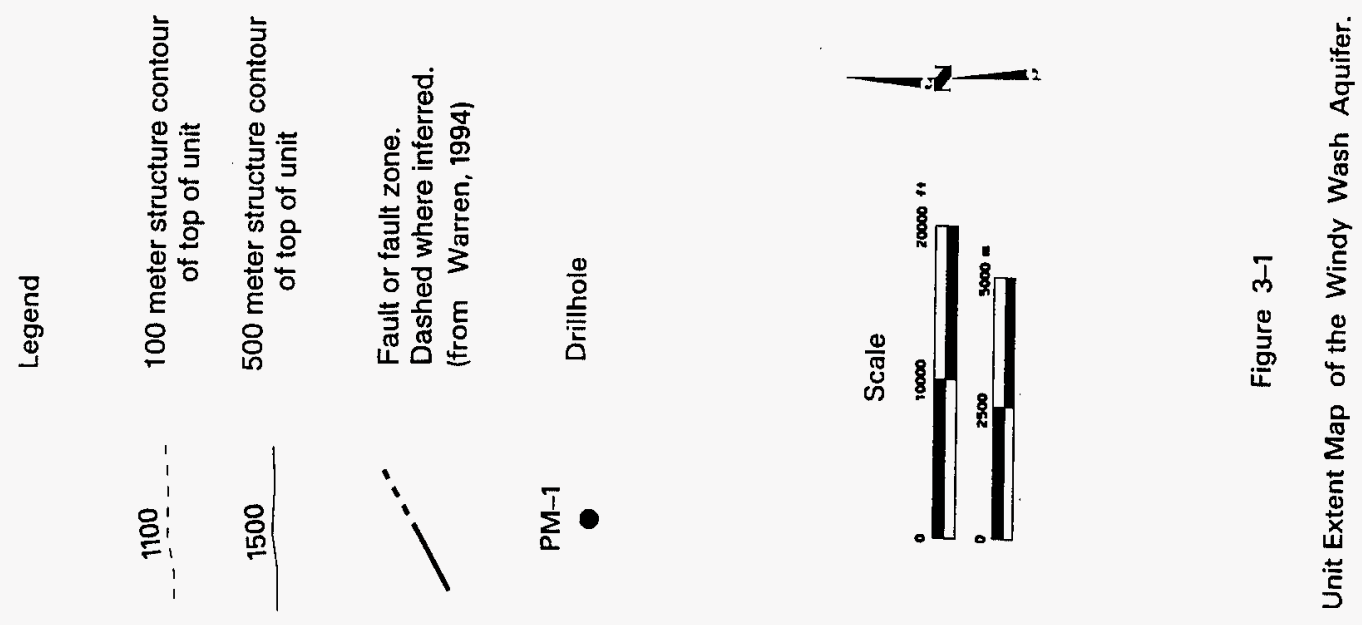

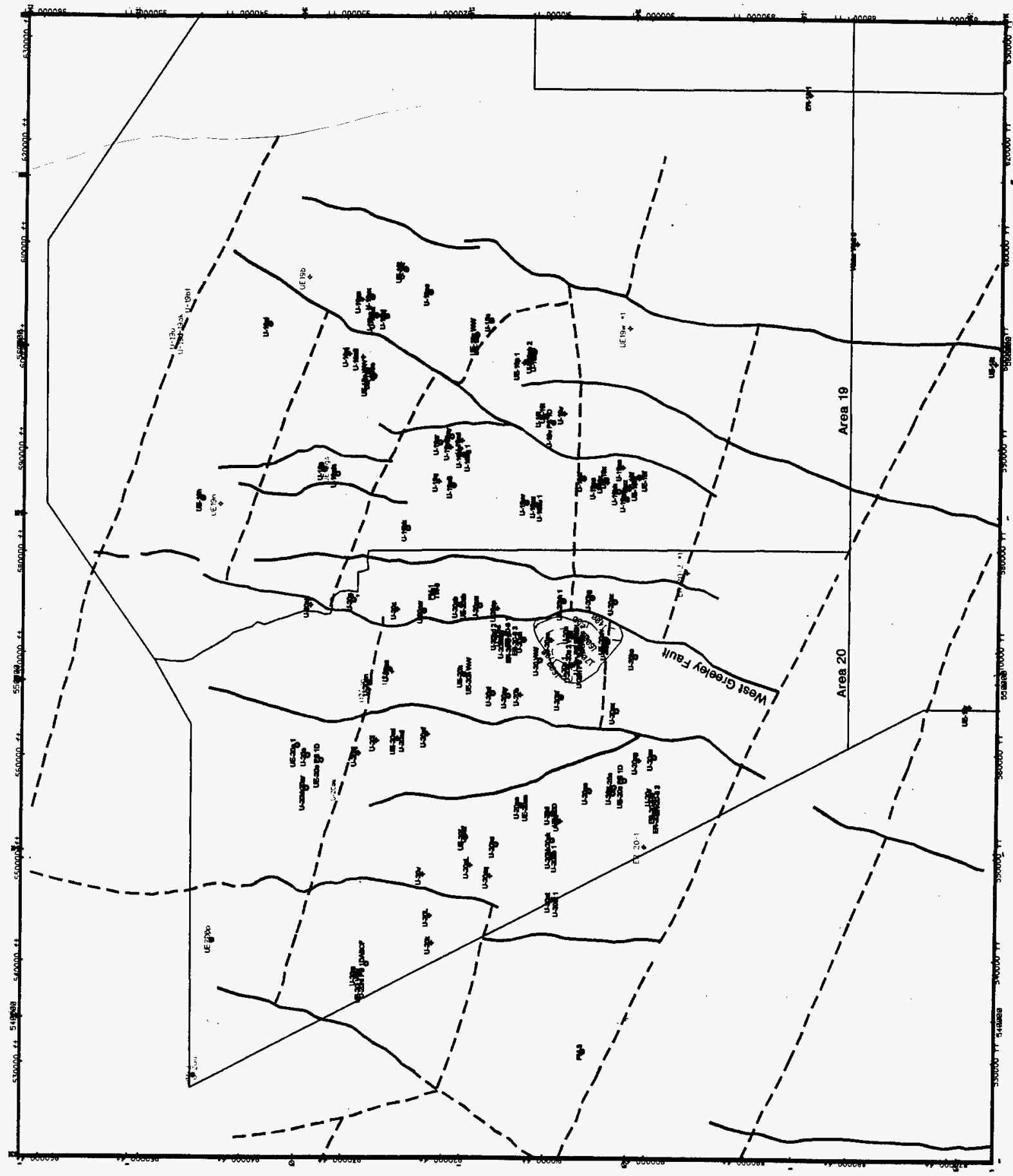




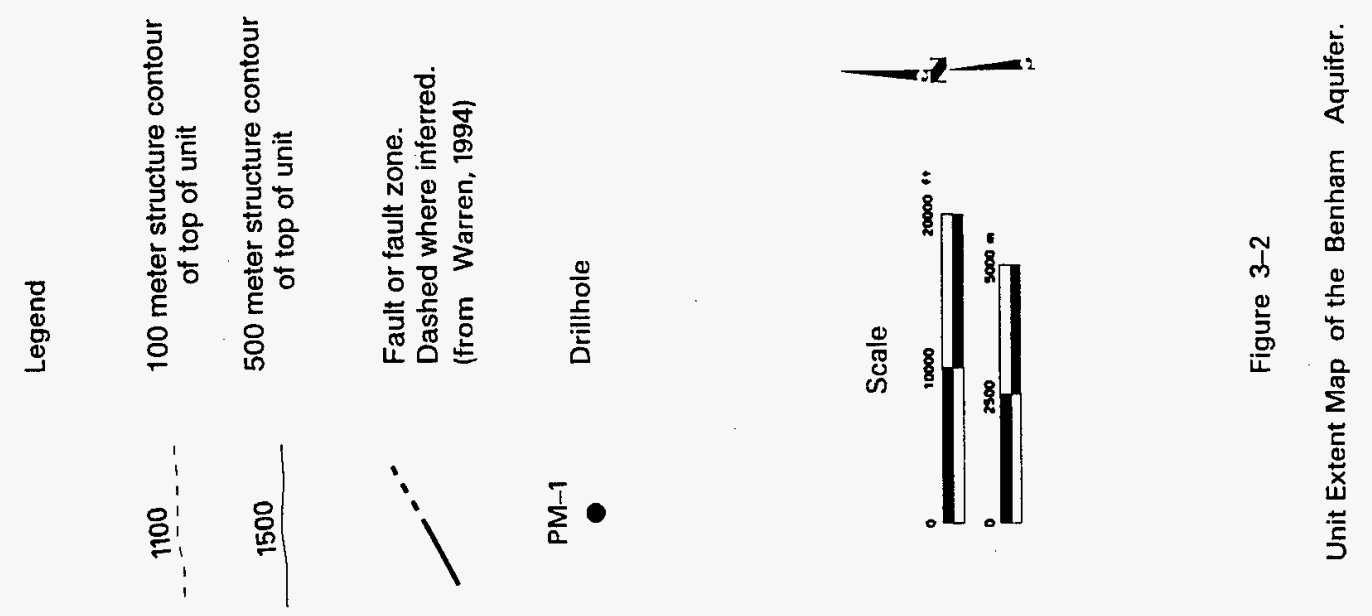

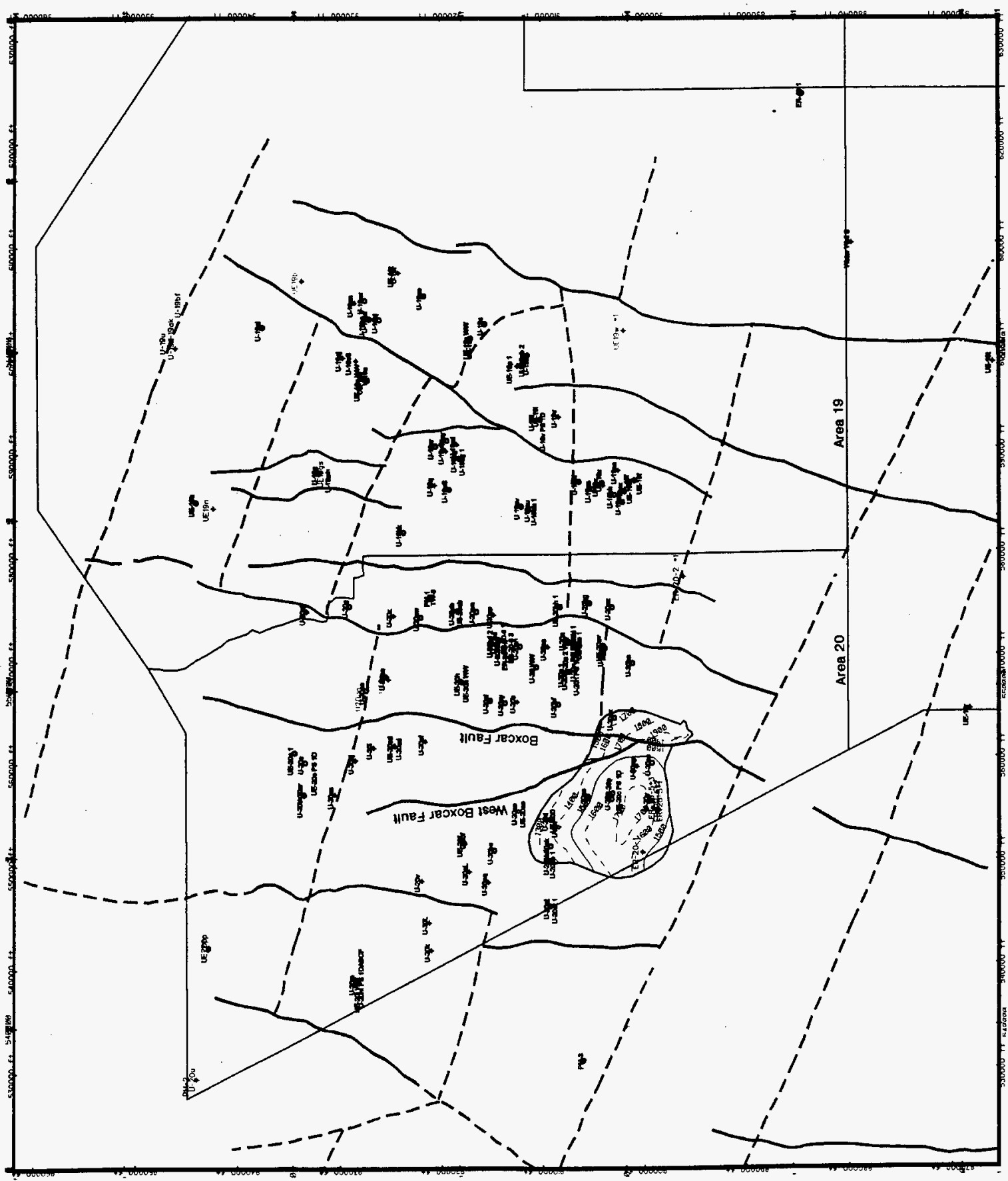



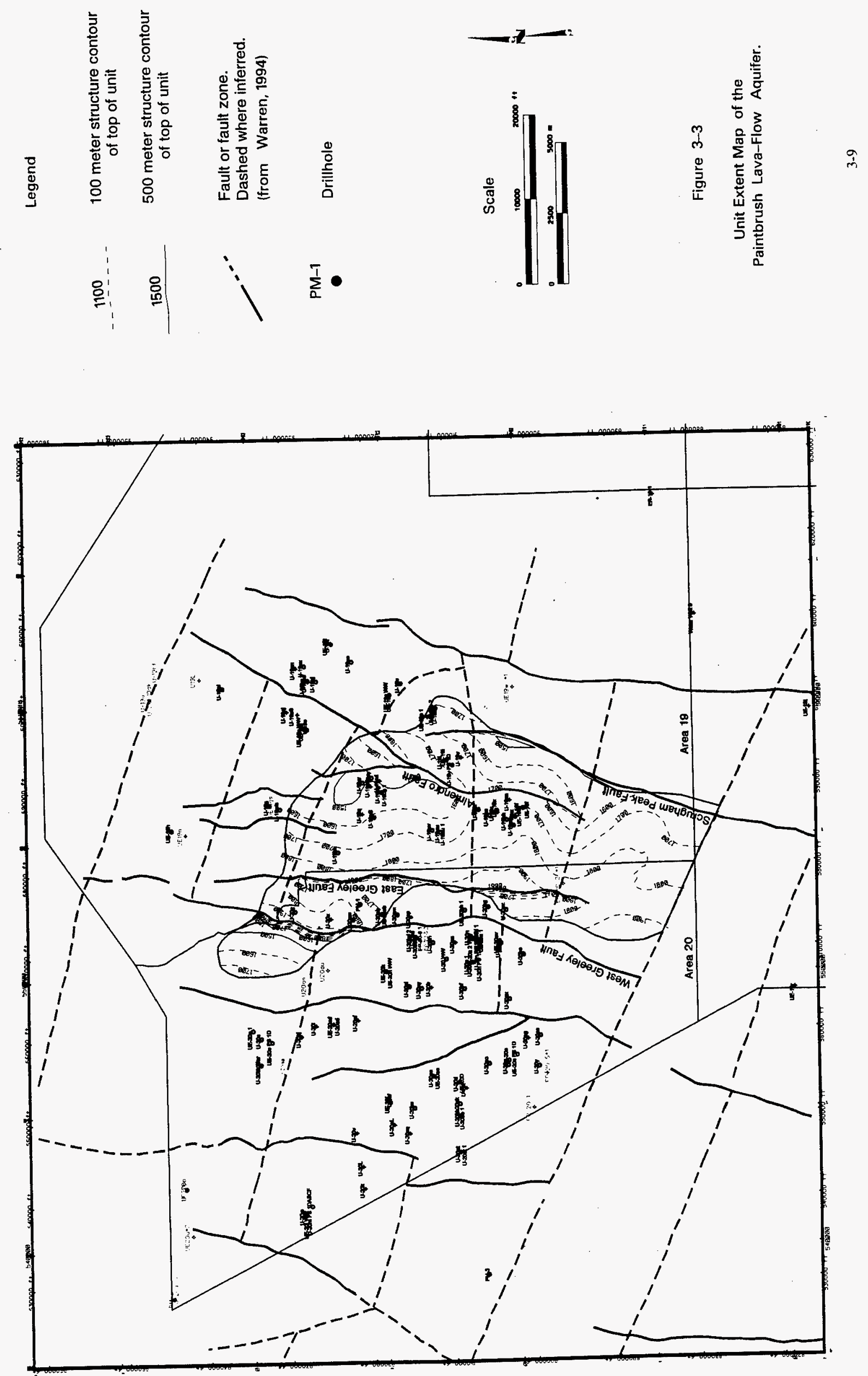
The northwestern portion of the Paintbrush Lava-Flow Aquifer consists mostly of a single lava-flow aquifer composed of lava assigned to the older rhyolite of Silent Canyon. This lava appears to be more pumiceous than normal, possibly indicating a higher initial gas content, and thus a less viscous lava, which may explain the relatively thin $(<200 \mathrm{~m}[<656 \mathrm{ft}])$ nature of the unit in this area. Lava of the rhyolite of Silent Canyon appears to have been erupted along the East Greeley fault (east of U-20g) and flowed south between the East Greeley and Almendro faults (Warren et al., 1989).

The eastern and southern portions of the Paintbrush Lava-Flow Aquifer consist mostly of lava-flow aquifer overlying a lesser thickness of welded-tuff aquifer. Both of these hydrogeologic units are composed of lithologies assigned to the rhyolite of Echo Peak. Lava and ash-flow tuff of rhyolite of Echo Peak probably erupted just south of Pahute Mesa and flowed north onto Pahute Mesa, mostly between the East Greeley and Scrugham Peak faults (Warren et al., 1989). Northward flow of rhyolite of Echo Peak lava and ash-flow tuff appears to have been blocked and deflected to the northeast by the topographic high formed by the earlier eruption of rhyolite of Silent Canyon lava.

The Paintbrush Lava-Flow Aquifer occurs mostly above the water table; however, anomalously high water levels are present within the aquifer in several holes in the vicinity of U-19bh (O'Hagan and Laczniak, 1996): All of those holes bottom in the aquifer. Other holes in the vicinity that penetrate through the aquifer have normal water levels. Therefore, the anomalous levels probably represent perched water within the Paintbrush Lava-Flow Aquifer in this area. Two other caldera-burying lava flows of the Paintbrush Group are exposed in the south face of Pahute Mesa, straddling the East Greeley fault (Byers and Cummings, 1967). These flows have been assigned to the rhyolite of Scrugham Peak and the rhyolite of Delirium Canyon (Warren et al., 1989). Because both lava flows are unsaturated, appear to be of limited extent, and have not been encountered in Pahute Mesa drillholes, they have been included in the Paintbrush Vitric Tuff Aquifer hydrostratigraphic unit.

\subsubsection{Calico Hills Zeolitized and Vitric Composite Units}

The Area 20 caldera-filling Calico Hills Formation forms two hydrostratigraphic units that contain lava-flow aquifers: the Calico Hills Zeolitized Composite Unit and the Calico Hills Vitric Composite Unit. The Calico Hills Zeolitized Composite Unit is probably the most important hydrostratigraphic unit in much of Area 20. It consists of a complex threedimensional distribution of lava and zeolitized bedded and nonwelded tuff of the mafic-poor and mafic-rich members of the Calico Hills Formation. The hydrostratigraphic unit is 
dominated by the thicker and more extensive mafic-poor member which consists of at least three lava-flow aquifers separated by tuff confining units. Limited drillhole information, petrographic similarity, and the unpredictable occurrence of lava within both the mafic-poor and mafic-rich members precludes accurate correlation and mapping of individual lava-flow aquifers. The percentage of lava-flow aquifer within the Calico Hills Zeolitized Composite Unit ranges from 20 to 70 percent and appears to average about 50 percent. The unit is generally present west of the West Greeley fault and is thickest along the downthrown side of the fault in the vicinity of U-20n, where the unit approaches $1,300 \mathrm{~m}(4,265 \mathrm{ft})$ in thickness (Figure 3-4). The unit thins to the west until the lavas pinch out generally coincident with the western boundary of the Area 20 caldera. The eastern margin of the unit is drawn as a vertical boundary that separates predominately zeolitized tuffs of the Calico Hills Zeolitized Composite Unit from more vitric tuffs of the Calico Hills Vitric Composite Unit. To the north, the boundary is drawn at the approximate pinch-out of the lavas. The boundary of the Timber Mountain caldera complex forms the southern boundary.

Like the Calico Hills Zeolitized Composite Unit, the Calico Hills Vitric Composite Unit consists of lava and bedded and nonwelded tuffs of mainly the mafic-poor member of the Calico Hills Formation. However, the generally higher structural position of the Calico Hills Vitric Composite Unit has resulted in much of the bedded and nonwelded tuffs remaining vitric, particularly the upper portions of the unit. This may result in somewhat higher overall permeability for this hydrostratigraphic unit. The percentage of lava-flow aquifers within the Calico Hills Vitric Composite Unit appears to be approximately the same as that for the Calico Hills Zeolitized Composite Unit. The unit occurs in a rather limited area east of the West Greeley fault in east-central Area 20 and west-central Area 19 (Figure 3-5). It is thickest along its western margin in Area 20 where it is approximately $600 \mathrm{~m}(2,000 \mathrm{ft})$ thick. The western margin of the unit is the same as that for the eastern margin of the Calico Hills Zeolitized Composite Unit. The northern, southern, and eastern margins coincide with the pinch-out of the lavas.

\subsubsection{Inlet Aquifer}

The Inlet Aquifer consists of lava and minor zeolitized bedded and nonwelded tuff of the Area 20 caldera-filling rhyolite of Inlet. Thus, the Inlet Aquifer consists mostly of lava-flow aquifer, with only minor amounts of tuff confining unit. Only a few drillholes at Pahute Mesa are deep enough to have encountered the rhyolite of Inlet. Therefore, conclusions on the extent, thickness, and hydraulic character of the Inlet Aquifer are highly conjectural. 


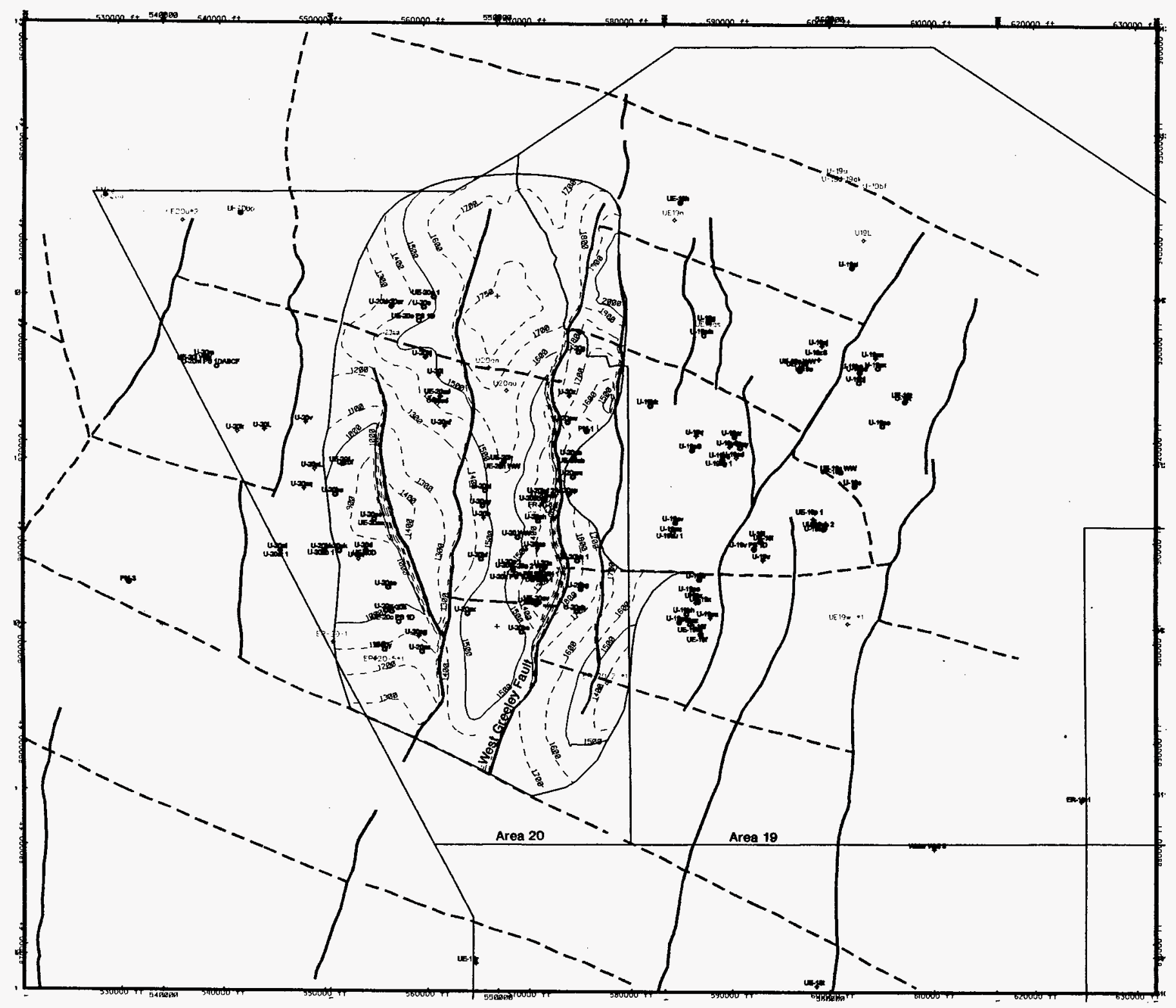

Legend

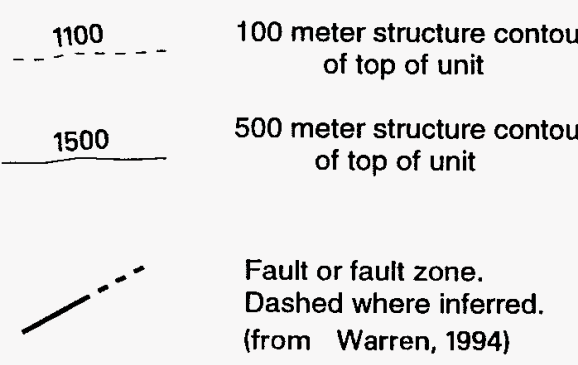

PM-1 Drillhole

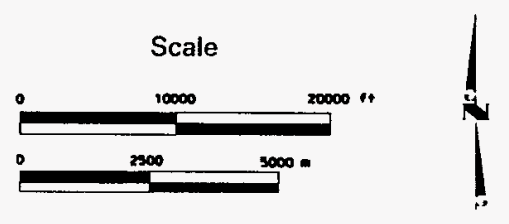

Figure 3-4

Unit Extent Map of the

Calico Hills Zeolitized Composite Unit. 

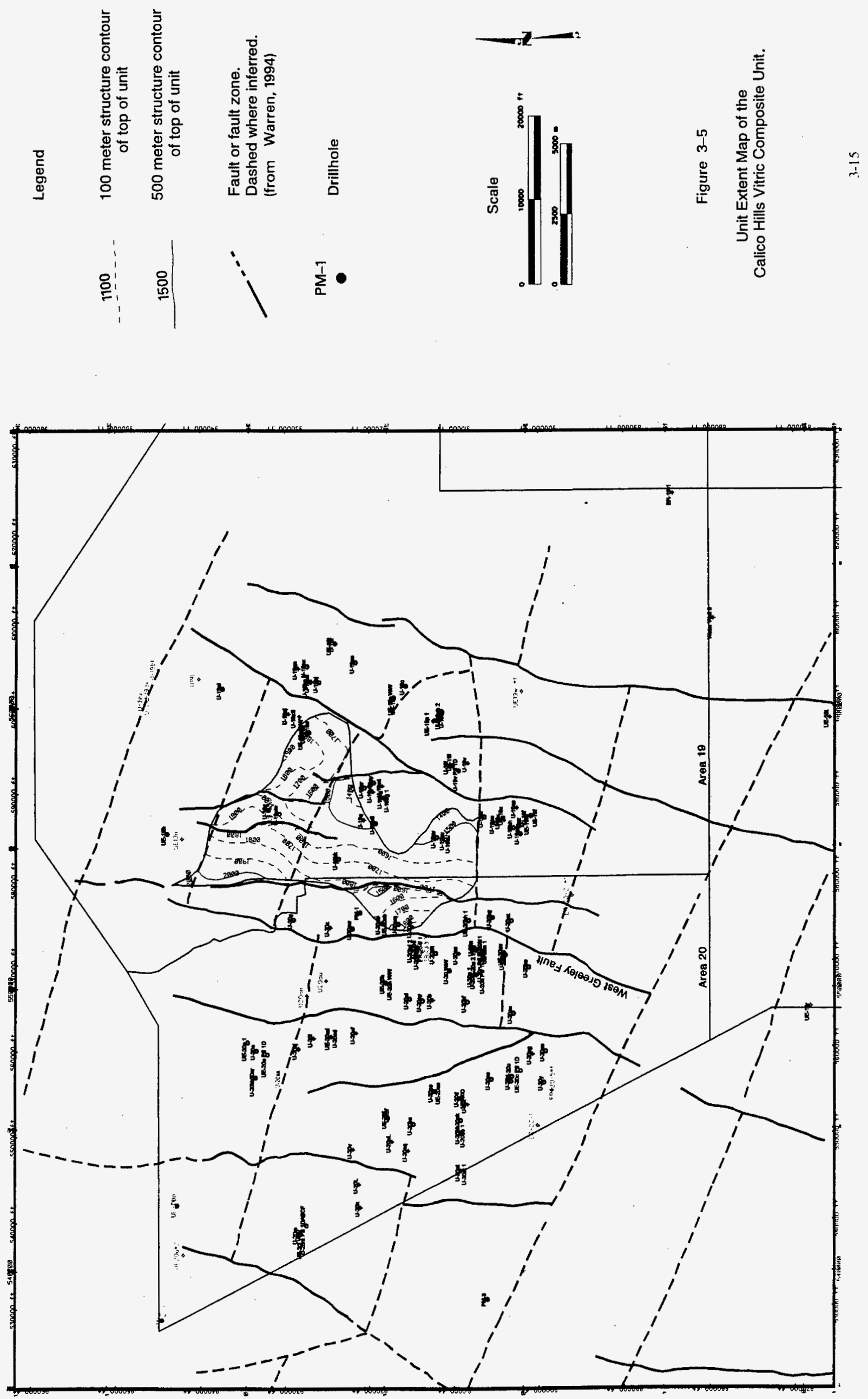
There appear to be two occurrences of the Inlet Aquifer at Pahute Mesa (Figure 3-6). One occurrence is within the outer collapse zone of the Area 20 caldera in southwestern Area 19 and the adjacent portion of southeastern Area 20. In this area the unit is defined by drillhole UE-19fS which penetrated $561 \mathrm{~m}(1,840 \mathrm{ft})$ of the rhyolite of Inlet consisting of 99 percent lava. Maximum thickness for this occurrence may be as much as $600 \mathrm{~m}(2,000 \mathrm{ft})$.

The other occurrence of Inlet Aquifer is in western Area 20 between the West Boxcar and Purse faults (Figure 3-6). Here this unit is defined by drillhole UE-20f which encountered $381 \mathrm{~m}(1,250 \mathrm{ft})$ of rhyolite of Inlet, of which 84 percent is lava. Lava of the rhyolite of Inlet in western Area 20 was probably erupted south of Pahute Mesa and flowed north. Deposition appears to have been controlled by the Purse fault on the west and the West Boxcar fault on the east (Warren et al., 1989).

\subsubsection{Crater Flat Composite Unit .}

The Crater Flat Composite Unit occurs west of the West Greeley fault mainly within the Area 20 caldera (Figure 3-7). This hydrostratigraphic unit consists of lava-flow and weldedtuff aquifers, and tuff confining units of mainly the tuff of Jorum and underlying rhyolite of Sled, both Area 20 caldera-filling units. Like the Inlet Aquifer, few drillholes are deep enough to penetrate this hydrostratigraphic unit and, therefore, conclusions on its distribution and hydrologic character are highly conjectural.

The tuff of Jorum appears to be relatively thin and sporadic at Pahute Mesa (Warren et al., 1989). However at UE-20h, over $490 \mathrm{~m}(1,600 \mathrm{ft})$ were encountered, including $239 \mathrm{~m}$

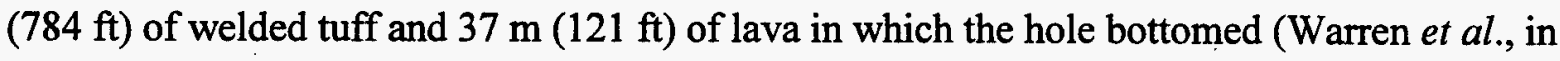
preparation). This anomalously thick section of tuff of Jorum suggests that the main site of tuff of Jorum caldera-filling deposition is west of the West Greeley fault. This is also the site of thick occurrences of other Area 20 caldera-filling units such as rhyolite of Inlet and Calico Hills Formation. If it is assumed that the lithologic makeup of tuff of Jorum is similar to that of other Area 20 caldera-filling units, then tuff of Jorum west of the West Greeley fault should consist of lava and welded tuff interbedded and intercalated with zeolitized bedded and nonwelded tuff. This lithologic distribution is consistent with a Composite Unit hydrostratigraphic designation.

The lower portion of the Crater Flat Composite Unit probably consists of lava and bedded and nonwelded tuff of the rhyolite of Sled. Little is known of this formation west of the West Greeley fault. However, because it is a caldera-filling unit, it is assumed to have a similar 
This Page Intentionally Left Blank 

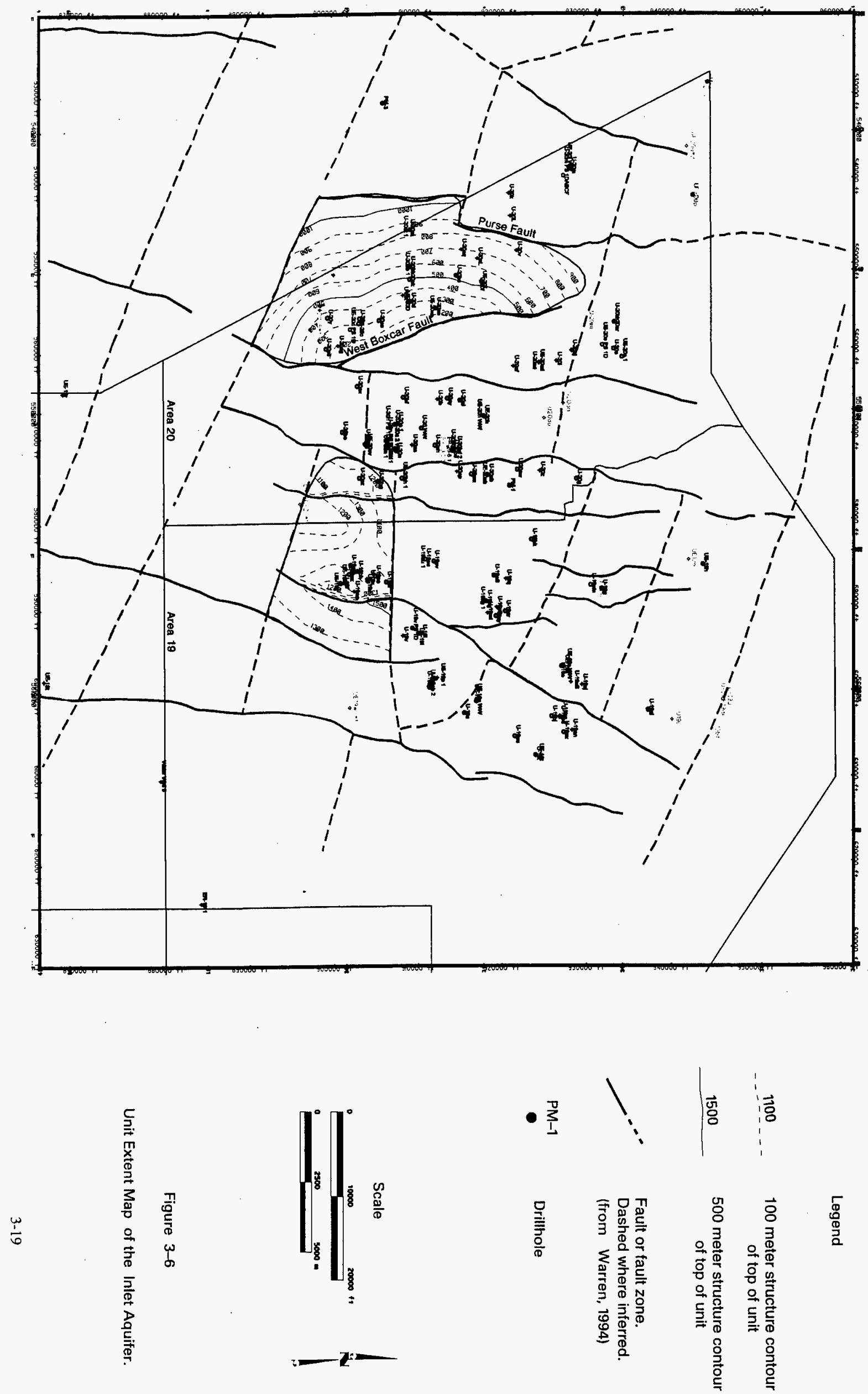


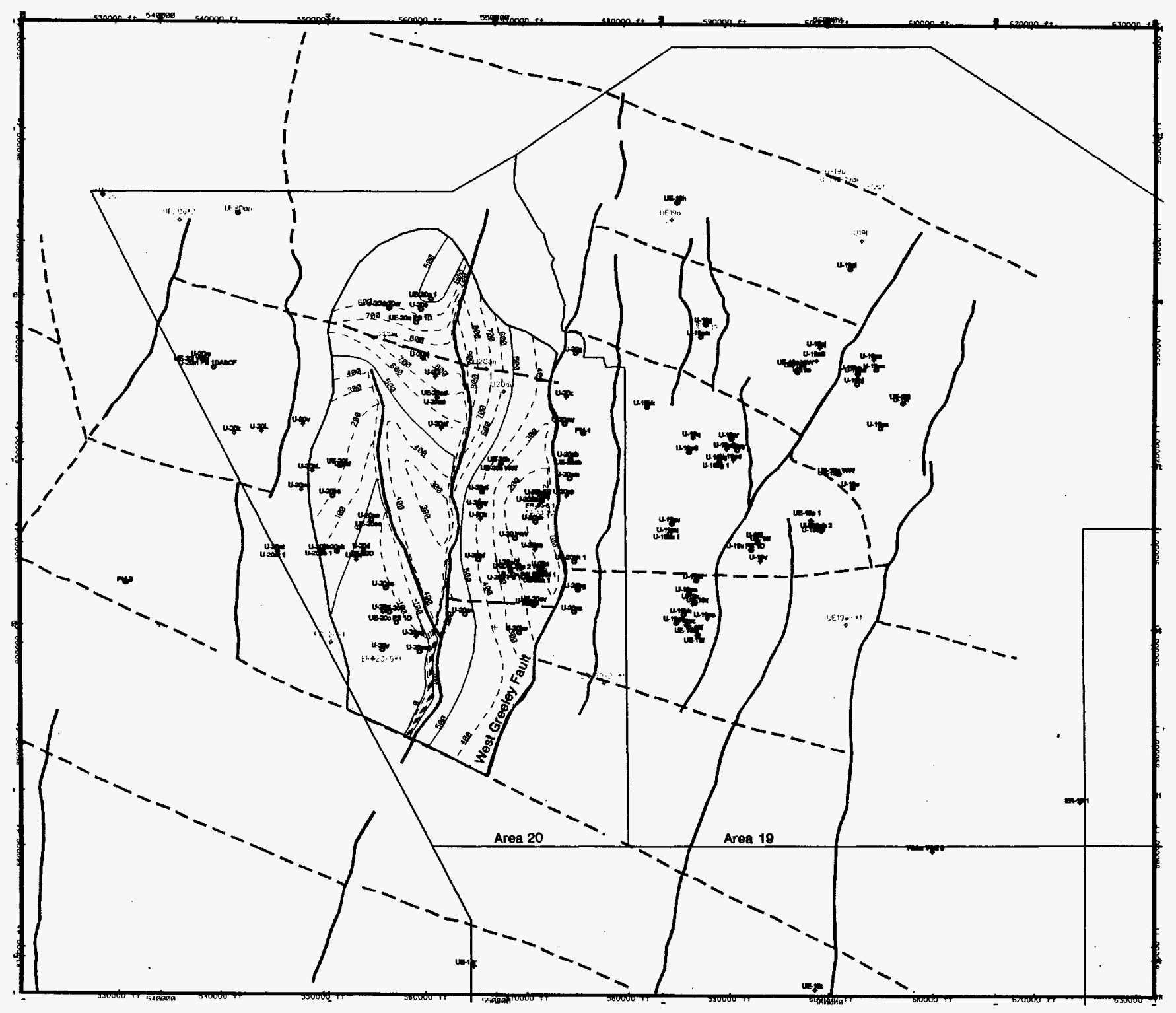

Legend

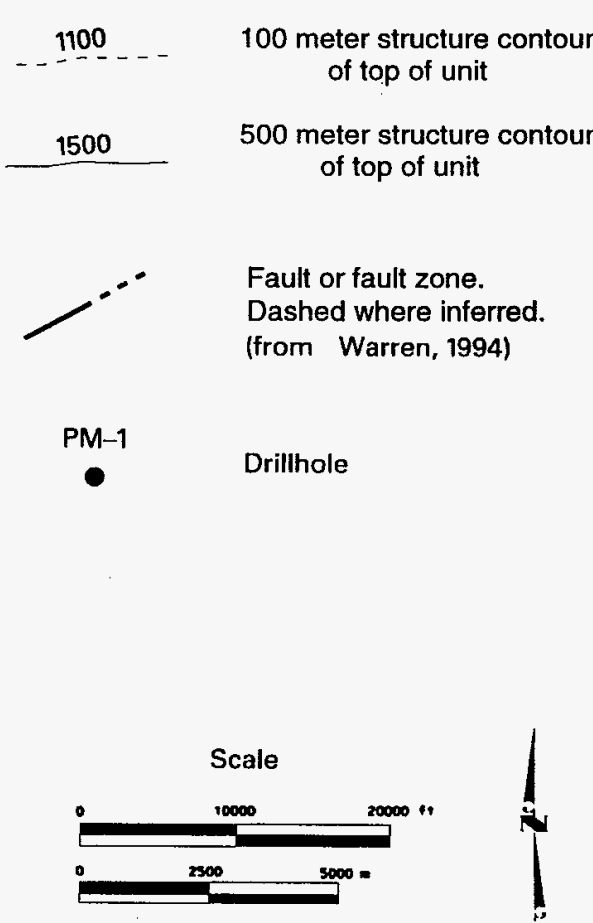

Figure 3-7

Unit Extent Map of the Crater Flat Composite Unit. 
lithologic and hydrogeologic makeup and distribution similar to that of the tuff of Jorum. East of the West Greeley fault at U-19a/s, $88 \mathrm{~m}(289 \mathrm{ft})$ of lava assigned to the rhyolite of Sled is present. However, this is the only significant occurance of rhyolite of Sled lava east of the West Greeley fault.

\subsubsection{Kearsarge Aquifer}

The Kearsarge Aquifer, located in north-central Area 19, consists of a single interval of lavaflow aquifer, the rhyolite of Kearsarge (Figure 3-8). The hydrostratigraphic unit is limited in extent and relatively thin, having a maximum thickness of approximately $200 \mathrm{~m}(650 \mathrm{ft})$.

The Kearsarge Aquifer is mostly unsaturated. However, the water level measurement at U-19ba, within the Kearsarge Aquifer, is anonymously high in the area, and may represent perched or semiperched water within the Kearsarge Aquifer (O'Hagan and Laczniak, 1996).

\subsubsection{Belted Range Aquifer}

The Belted Range Aquifer is composed mainly of lava-flow and welded-tuff aquifers consisting of lava and welded ash-flow tuff of the Belted Range Group which formed and filled the Grouse Canyon caldera (Ferguson et al., 1994). Minor intercalated tuff confining unit is also present within the unit. The Belted Range Aquifer underlies most of Areas 19 and 20 (Figure 3-9). It is very thick, particularly within the Grouse Canyon caldera where it as much as $2,000 \mathrm{~m}(6,500 \mathrm{ft})$ thick. Lava-flow aquifer is probably the most abundant hydrogeologic unit within the Belted Range Aquifer, particularly in Area 20 and the upper and lower portions of the unit in Area 19. The middle portion of the unit beneath Area 19 consists of thick welded-tuff aquifer of the caldera-forming Grouse Canyon Tuff. Except for the northern and eastern portions of Area 19, the Belted Range Aquifer is probably completely saturated.

\subsubsection{Pre-Belted Range Composite Unit}

Thick accumulations of tuff and lava that predate the Belted Range Group are believed to underlie Pahute Mesa (Figure 3-10). Very little is known about these deep rocks beneath Pahute Mesa. However, exposures of these rocks in other areas indicate they consist of lava, welded ash-flow tuff, nonwelded tuff, and bedded tuff, forming an unknown distribution of lava-flow and welded-tuff aquifers and tuff confining units. However, data from the few drillholes that encounter these rocks beneath Pahute Mesa indicate that in places they are strongly hydrothermally altered, and thus poorly transmissive (Warren, personal communication). 
This Page Intentionally Left Blank 


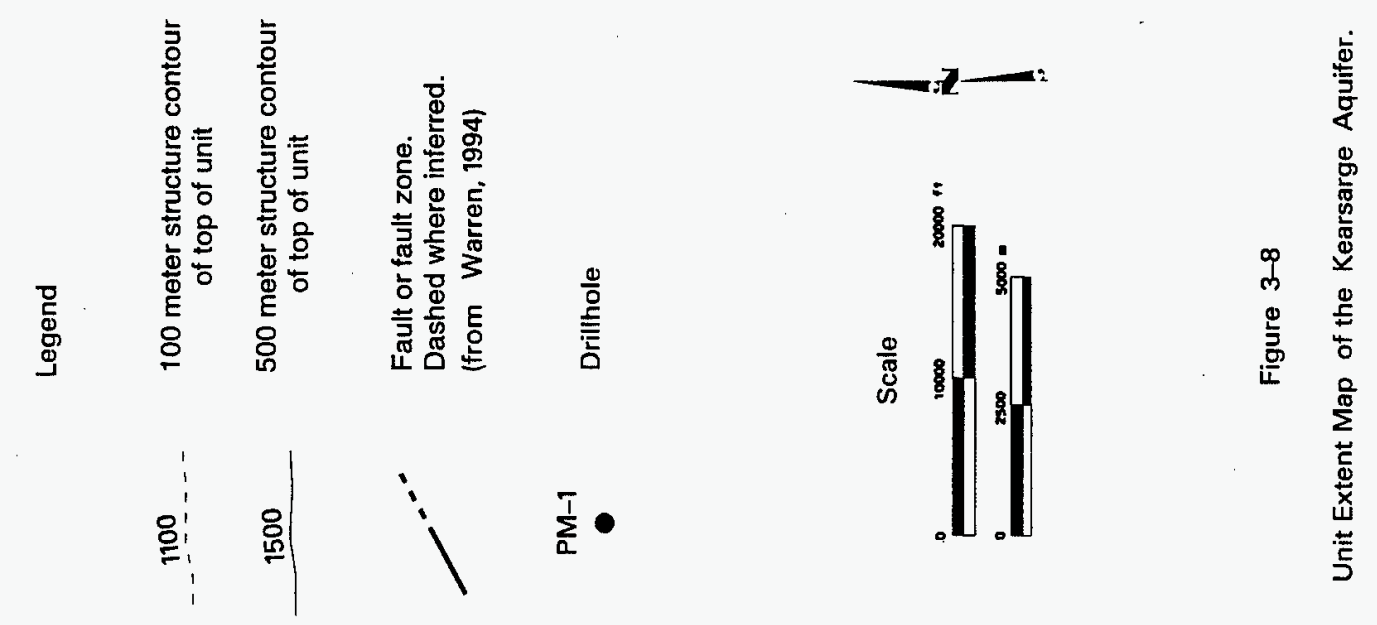

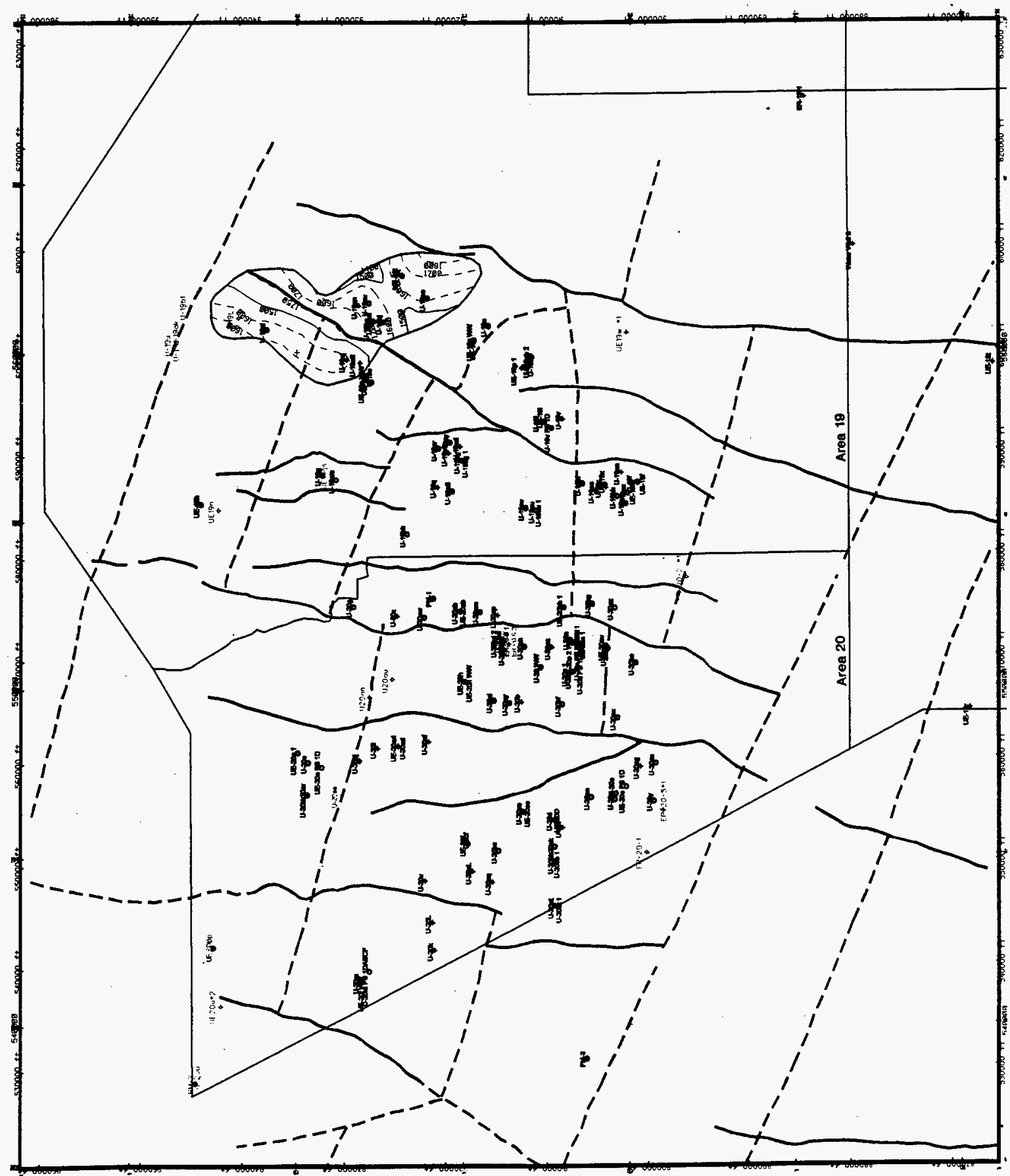



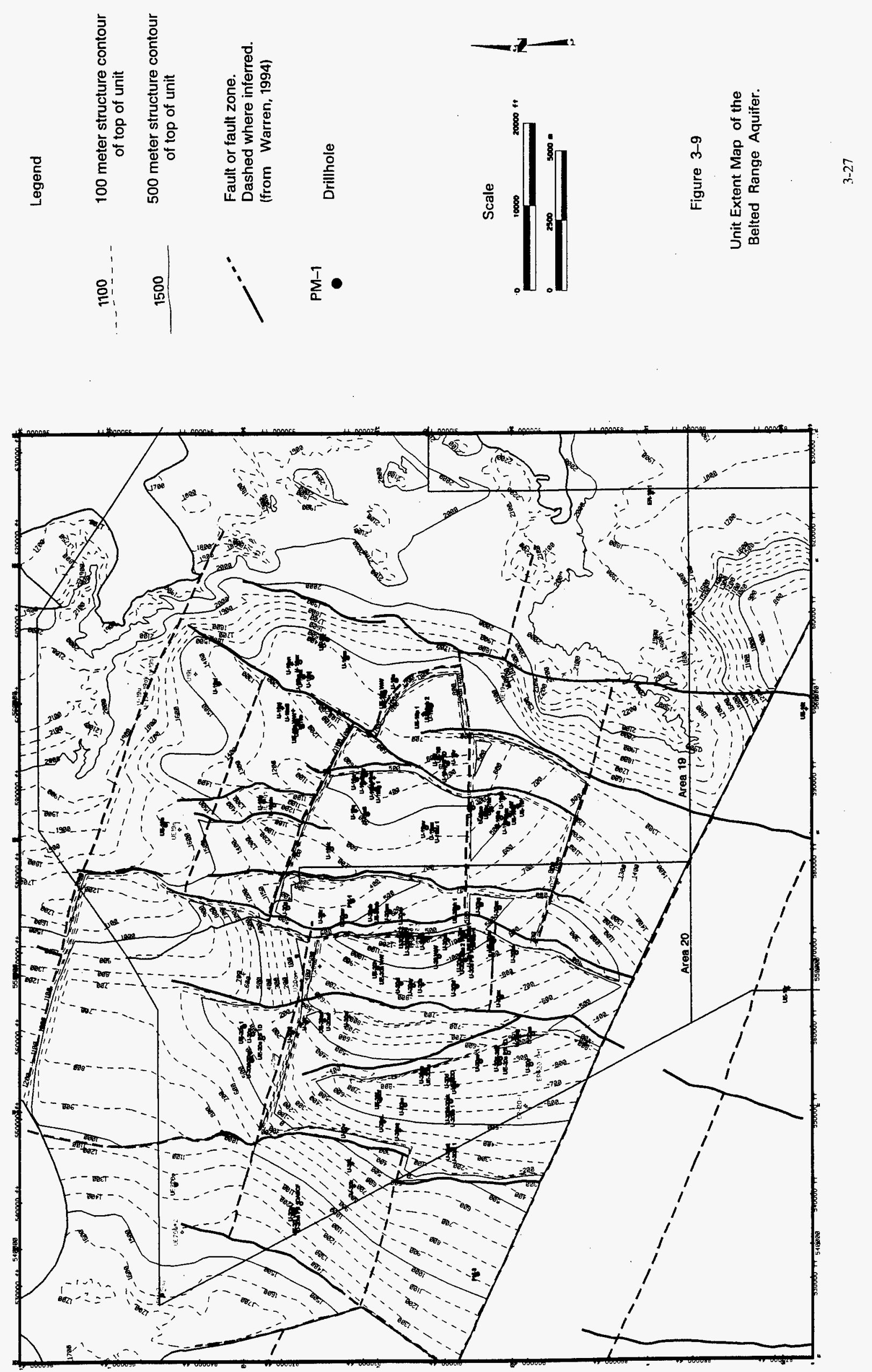


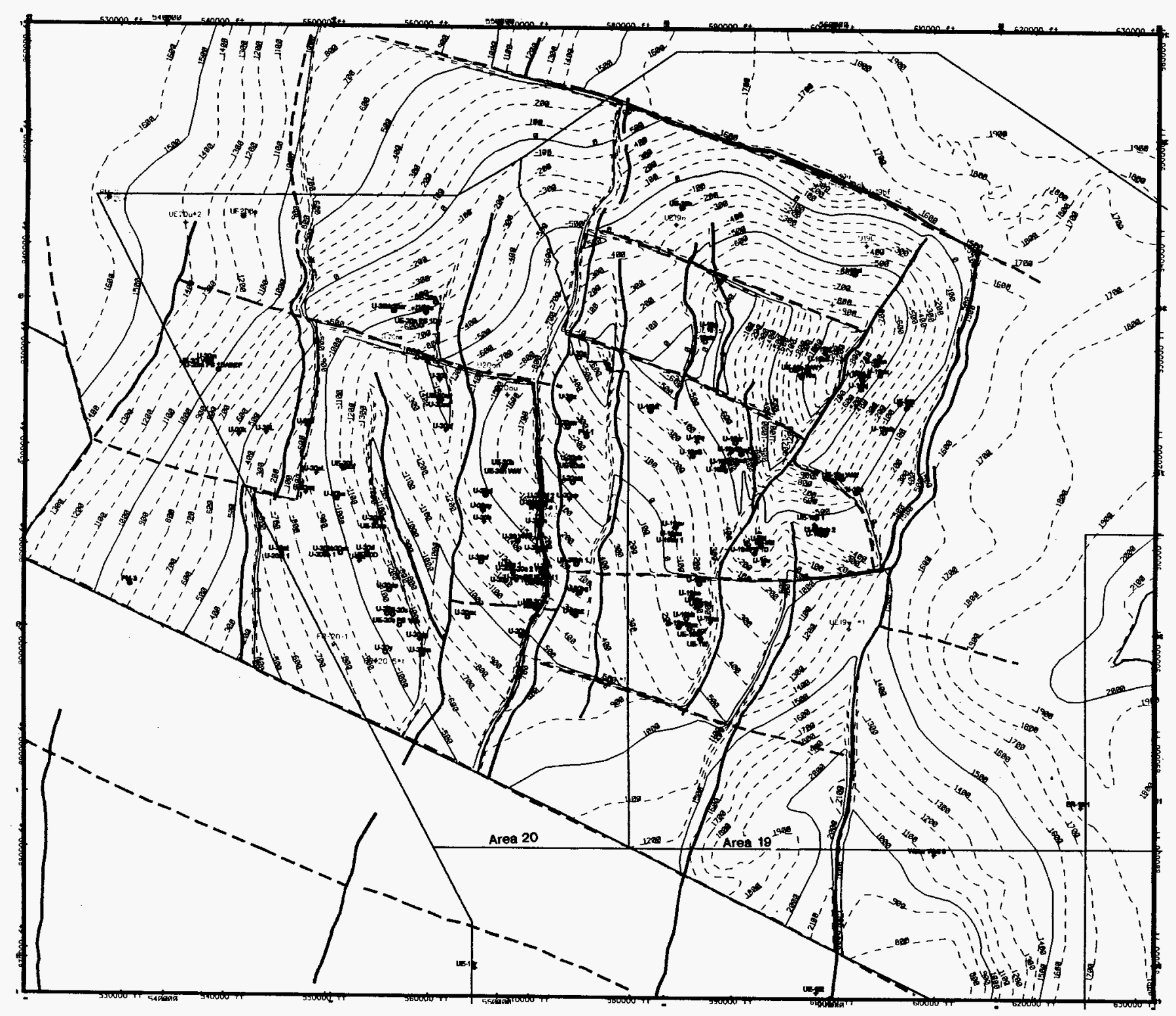

Legend
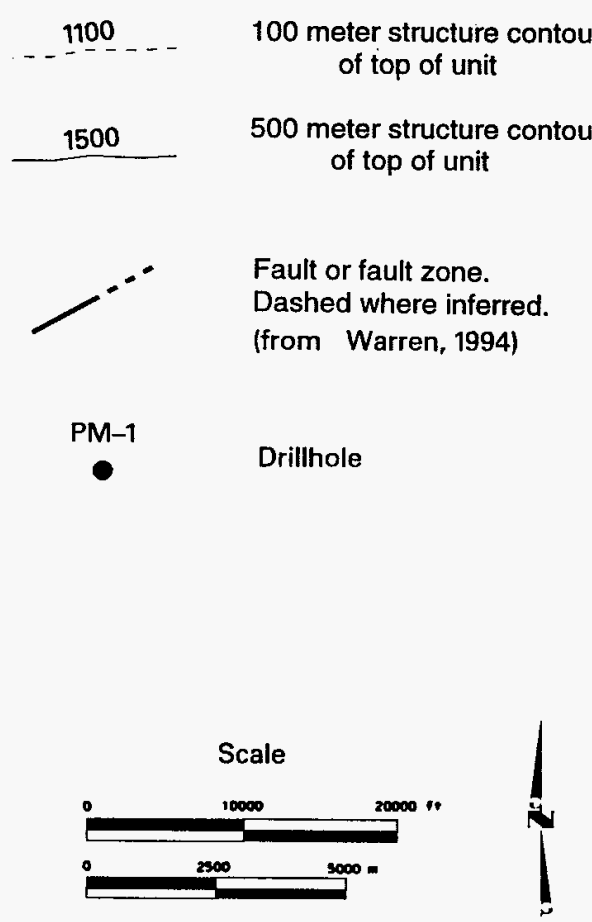

Figure 3-10

Unit Extent Map of the Pre-Belted Range Composite Unit. 


\subsection{SUMMARY}

Much of the groundwater beneath eastern Pahute Mesa flows within lava-flow aquifers (Blankennagel and Weir, 1973) consisting of fractured rhyolite lava flows. These lava flows can consist of a variety of lithologies, including stony and pumiceous lava, vitrophyre, and flow breccia, each of which can have significantly different hydrologic properties. This heterogeneity results in groundwater flow paths within lava-flow aquifers that can be quite tortuous. Consequently, on a gross scale lava-flow aquifers probably transmit groundwater less effectively than welded-tuff aquifers. However, in certain places within the aquifer, such as the fractured stony interiors and the basal flow breccia, the aquifer can have permeability equal to or possibly greater than that of welded-tuff aquifer. Zones of higher permeability within lava-flow aquifers also occur in the vicinity of faults (Blankennagel and Weir, 1973).

Understanding the vertical and lateral distribution of lava-flow aquifers beneath eastern Pahute Mesa was critical to developing the hydrostratigraphic framework for the Pahute Mesa Study Area groundwater modeling effort. Lava-flow aquifers are found in 10 of the 21 volcanic hydrostratigraphic units that are present at Pahute Mesa. Unit extent maps consisting of structure contour maps of the upper surface of each of these ten units were produced. These hydrostratigraphic units range in composition and extent from a single lavaflow aquifer of very limited extent, such as the Windy Wash Aquifer, to very thick and extensive units, such as the Belted Range Aquifer. Also, several thick intervals of lava-flow aquifer may be separated by thick intervals of tuff confining units that have considerable lateral extent, such as the Calico Hills Zeolitized Composite Unit. 
This Page Intentionally Left Blank 
Blankennagle, R. K. and J. E. Weir, Jr., 1973. Geohydrology of the Eastern Part of Pahute Mesa, Nevada Test Site, Nye County, Nevada. U. S. Geological Survey Professional Paper 712-B.

Byers, F. M., Jr., and D. Cummings, 1967. Geologic Map of the Scrugham Peak Quadrangle, Nye County, Nevada. U. S. Geological Survey Geologic Quadrangle Map GQ-695, scale $1: 24,000$.

Cas, R. A. F. and J. V. Wright, 1987. Volcanic Successions. Allen and Unwin, London. pp. 79-87.

Christiansen, R. L. and D. C. Noble, 1968. Geologic Map of the Trail Ridge Quadrangle, Nye County, Nevada. U. S. Geological Survey Geologic Quadrangle Map GQ-774, scale $1: 24,000$.

Drellack, S. L., Jr., and L. B. Prothro (in preparation). Descriptive Narrative for the Hydrogeologic Model of the Western and Central Pahute Mesa Corrective Action Units. Bechtel Nevada report.

Ekren, E. B., R. E. Anderson, P. P. Orkild, and E. N. Hinrichs, 1966. Geologic Map of the Silent Butte Quadrangle, Nye County, Nevada. U. S. Geological Survey Geologic Quadrangle Map $G Q-493$, scale 1:24,000.

Federal Facility Agreement and Consent Order, 1996. Agreed to by the State of Nevada, the U. S. Department of Energy, and the U. S. Department of Defense.

Ferguson, J. F., A. H. Cogbill, and R. G. Warren, 1994. A Geophysical-Geological Transect of the Silent Canyon Caldera Complex, Pahute Mesa, Nevada. Journal of Geophysical Research, 99, pp. 4323-4339.

FFACO, see Federal Facility Agreement and Consent Order.

Frizzell, V. A., Jr., and J. Shulters, 1990. Geologic Map of the Nevada Test Site. U.S. Geological Survey Miscellaneous Investigation Series Map I-2046 (scale 1:100,00), Washington, DC.

Hinrichs, E. N., R. D. Krushensky, and S. J. Luft, 1967. Geologic Map of the Ammonia Tanks Quadrangle, Nye County, Nevada. U. S. Geological Survey Geologıc Qhuadrangle Map, GQ-638, scale 1:24,000.

IT, see International Technologies Corporation.

International Technologies Corporation, 1995. Potentiometric Data Task Dxcumentation Package. U. S. Department of Energy draft report. 
International Technologies Corporation, 1996a. Underground Test Area Fracture Analysis Report: Analysis of Fractures in Volcanic Cores from Pahute Mesa. U.S. Department of Energy draft report.

International Technologies Corporation, 1996b. Underground Test Area Project Phase I Data Analysis Task, Regional Geologic Model Data Documentation Package. U. S. Department of Energy draft report.

Kane, M. F., M. W. Webring, and B. K. Bhattacharyya, 1981. A Preliminary Analysis of Gravity and Aeromagnetic Surveys of the Timber Mountain Area, Southern Nevada. U.S. Geological Survey Open-File Report 81-189.

Laczniak, R. J., J. C. Cole, D. A. Sawyer, and D. A. Trudeau, 1996. Summary of Hydrogeologic Controls on the Movement of Groundwater at the Nevada Test Site, Nye County, Nevada. U.S. Geological Survey, Water-Resources Investigations Report 96-4109, Carson City, Nevada.

Lipman, P. W., W. D. Quinlivan, W. J. Carr, and R. E. Anderson, 1966. Geologic Map of the Thirsty Canyon SE Quadrangle, Nye County, Nevada. U. S. Geological Survey Geologic Quadrangle Map GQ-489, scale, 1:24,000.

Los Alamos National Laboratory and U.S. Geological Survey, 1992. Pre-drilling and Hydrologic Prospectus for Groundwater Characterization Hole ER-20-2, Pahute Mesa, Nevada Test Site. Informal technical report prepared for the Underground Test Area project, February 19, 1992.

Maley, T. S., 1994. Field Geology Illustrated. Mineral Land Publications, Boise, Idaho. pp. 220-227.

Minor, S. A., D. A. Sawyer, R. R. Wahl, V. A. Frizzell, Jr., S. P. Schilling, R. G. Warren, P. P. Orkild, J. A. Coe, M. R. Hudson, R. J. Fleck, M. A. Lanphere, WC Swadley, and J. C. Cole, 1993. Preliminary Geologic Map of the Pahute Mesa 30' x 60' Quadrangle, Nevada. U. S. Geological Survey Open-File Report 93-299.

Noble, D.C., R. D. Krushensky, E. J. McKay, and J. R. Ege, 1967. Geologic Map of the Dead Horse Flat Quadrangle, Nye County, Nevada. U. S. Geological Survey Geologic Quadrangle Map GQ-614, scale 1:24,000.

Noble, D. C., K. A. Sargent, H. H. Mehnert, E. B. Ekren, and F. M. Byers, Jr., 1968. Silent Canyon Volcanic Center, Nye County, Nevada, in Nevada Test Site, U. S. Geological Survey Memoir 110, pp 65-75.

O'Hagan, M. D., and R. J. Laczniak, 1996. Ground-Water Levels Beneath Eastern Pahute Mesa and Vicinity, Nevada Test Site, Nye County, Nevada. U.S. Geological Survey Water-Resources Investigations Report 96-4042, Carson City, Nevada. 
Orkild, P. P., F. M. Byers, Jr., D. L. Hoover, and K. A. Sargent, 1968. Subsurface Geology of Silent Canyon Caldera, Nevada Test Site, Nevada, in Nevada Test Site, U. S. Geological Survey Memoir 110, pp 75-86.

Orkild, P. P., K. A. Sargent, and R. P. Snyder, 1969. Geologic Map of Pahute Mesa, Nevada Test and Vicinity, Nye County, Nevada, U. S. Geological Survey Miscellaneous Geologic Investigations Map 1-567, scale 1:48,000.

Sawyer, D. A., and K. A. Sargent, 1989. Petrographic Evolution of Divergent Peralkaline Magmas from the Silent Canyon Caldera Complex, Southwestern Nevada Volcanic Field. Journal of Geophysical Research, 94, pp. 6021-6040.

Warren, R. G., 1994. Structural Elements and Hydrogeologic Units of the Southwestern Nevada Volcanic Field. Informal Los Alamos National Laboratory technical report prepared for the Underground Test Area project, January 19, 1994.

Warren, R. G., D. A. Sawyer, and H. R. Covington, 1989. Distinguishing Characteristics of Stratigraphic Units of Pahute Mesa, Attachment 2 of a Los Alamos National Laboratory informal technical report prepared for the Nevada Test Site underground nuclear testing community, July $26,1989$.

Warren, R. G., D. A. Sawyer, F. M. Byers, Jr., and G. L. Cole (in preparation). A Petrographic/Geochemical Database and Stratigraphic and Structural Framework for the Southwestern Nevada Volcanic Field. Los Alamos National Laboratory Report.

Winograd, I. J., and W. Thordarson, 1975. Hydrogeologic and Hydrochemical Framework, South-Central Great Basin, Nevada-California, with Special Reference to the Nevada Test Site. U.S. Geological Survey Professional Paper 712-C. 


$$
\text { F }
$$


M98050560

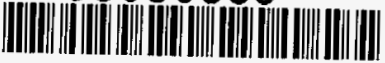

Report Number (14)DOE/NV/i1718--156

Publ. Date (11) 199709

Sponsor Code (18) DOE/DP, XF

UC Category (19) UC-703, DOE/ER

DOE 